DOCTRINA

\title{
La genealogía del derecho penal democrático: Una polémica moral
}

\author{
The Genealogy of Democratic Criminal Law: \\ A Moral Polemic
}

Nicolás Otero Álvarez (iD

Abogado, Colombia

\begin{abstract}
RESUMEN Este trabajo trata acerca del fundamento y la legitimación del derecho penal, en especial sobre los límites teóricos tanto de la teoría del delito como de la teoría de la pena. El objetivo es explicar en qué consiste el derecho penal en el contexto de una democracia e indagar por sus orígenes en la modernidad y su arraigo en la conciencia occidental. Por este motivo, el lector podrá encontrar una explicación de las teorías expresivas y retributivas de la pena, así como del concepto actual de libertad normativa. Se trata de un texto profundamente crítico basado en Friedrich Nietzsche.
\end{abstract}

PALABRAS CLAVE Libertad, democracia, cristianismo, sociedad occidental, modernidad.

ABSTRACT This essay concerns the foundation and legitimacy of criminal law; that is, it has to do with the limits of the theory of crime and the theories of punishment. The objective of the author is to explain what criminal law consists of in the context of democracy, as well as to investigate its origins in modernity and its roots in Western thought. Therefore, the reader will find an explanation of the communicational and retributive theories of punishment, as well as the current concept of normative liberty. The text is highly critical and is based on the works of Friedrich Nietzsche.

KEYWORDS Freedom, democracy, Christianity, Western society, modernity. 


\section{Introducción}

Comencemos con una sentencia contemporánea: Se castiga porque el delincuente infringió las legítimas normas penales, aunque tuvo la posibilidad tanto de participar en su elaboración como de obedecerlas durante la ejecución de su conducta. Así, la deliberación legislativa y la imposición de la pena son las dos caras de una hoja cuyo sustrato es la voluntad. Por un lado, se dice cuáles son las normas vigentes para una sociedad democrática y, para redactar allí, es necesario que los ciudadanos puedan debatir y discutir sobre las razones que determinan que esa conducta sea sancionada. Del otro, actuando de forma opuesta a la establecida en el proceso democrático y pudiendo acatar los mandatos del derecho penal, el delincuente comunica que las normas expresadas en la contracara son inválidas. En una sociedad estable, la pena censura este último discurso y, por más que el delincuente intente dar vuelta a la hoja y mostrar su mensaje, al ser normal y encontrarse en circunstancias de normalidad, sus palabras desviadas deben silenciarse.

La cuestión penal ha sido desarrollada de forma sofisticada en el contexto de la democracia. ¿Es acaso un cambio de fondo en relación con la valoración moral antes imperante? Las raíces de esta pregunta penetran la tierra de nuestras conciencias, donde las bases de la democracia se nutren del cristianismo. Pese a que en el transcurso del siglo XXI la fragilidad de las instituciones de la modernidad se ha hecho evidente, es nuestra intención demostrar que la fe en las estrellas es el enemigo oculto de todo orden al mismo tiempo democrático y noble, antes y después del auge del internet. Para esto, deificaremos y juzgaremos a la Democracia, la veremos de frente y por detrás, analizaremos todo lo que la rodea, y no pasarán desapercibidas aquellas ideas que evade como si, abochornada, tratara de olvidarlas. Ella tendrá que explicarnos por qué el criminal, en calidad de ser terrenal y libremente equivocado, es un sujeto sometido directamente a su autoridad. Su confesión será, para algunos, mirarse en el espejo.

De manera preliminar, y con el objeto de aclarar el lenguaje metafórico que se utiliza en diversas partes de este ensayo, considero conveniente narrar uno de los aforismos más famosos de la historia. Érase una vez un estupendo ser humano que buscaba a Dios entre unos ateos burlones con una linterna durante un iluminado atardecer. Por fin, dijo:

¡Dios ha muerto! ¡Dios permanece muerto! ¡Y nosotros lo hemos matado! ¿Cómo nos consolaremos, asesinos entre todos los asesinos? Lo más sagrado y poderoso que poseía el mundo hasta ahora se ha desangrado bajo nuestros cuchillos, - ¿quién quitará de nosotros esta sangre? ¿Con qué agua podríamos purificarnos? ¿Qué ceremonias expiatorias, qué juegos sagrados tendremos que inventar? ¿No es la grandeza de este acto demasiado grande para nosotros? ¿ ${ }^{N}$ o tenemos que volvernos nosotros mismos dioses para ser siquiera dignos de él? No ha habido nunca un acto más gran- 
de, - iy todo el que nazca después de nosotros formará parte, por ese acto, de una historia superior a toda historia habida hasta ahora! [...] Llego demasiado pronto, dijo entonces, no es aún mi tiempo. Este acontecimiento monstruoso está todavía en camino y se desplaza, —no ha llegado aún a los oídos de los hombres. El relámpago y el trueno necesitan tiempo, la luz de las estrellas necesita tiempo, los actos, para ser vistos y oídos, necesitan tiempo aún después de haber sido realizados. Este acto les sigue siendo más lejano que las estrellas más lejanas - $\mathrm{i} y$ sin embargo lo han hecho ellos mismos! - (Nietzsche, 2016: 169-170).

Ahora, es momento de introducir a la protagonista de este ensayo.

\section{Paseo de mediodía: El derecho penal democrático}

La Diosa de la Democracia ha escrito en una hoja el título Derecho penal. A lo lejos, se alcanzan a leer unas preguntas: «¿A quiénes me es permitido castigar? ¿Por qué debo hacerlo? ¿Cómo funciona el castigo? ¿Qué me legitima para actuar de esta forma?» La respuesta a estos interrogantes nos desembrollará el sentido que - para la Diosatiene la sentencia con la que hemos comenzado este ensayo.

\section{¿A quiénes me es permitido castigar?}

Esta es una de las cuestiones que más asalta en las noches a la Democracia, sus sueños y sus pesadillas la despiertan agitadamente. ${ }^{1}$ Ella no quiere ser hipócrita, es una dama respetable de varios siglos y quiere mantener su reputación. Sin embargo, hay algo que no la deja regir en paz en sus dominios, es una carcajada que viene del fondo del mar. ${ }^{2}$ No sabe bien si se trata de un mar profundo o de uno de esos que se tiñeron de palabras tercas e histéricas. ${ }^{3}$ Es una risa maligna y siempre que la escucha recuerda que jella misma! puede morir. En el fondo se alcanzan a ver los recuerdos de otras ideas, frases, proposiciones y enunciados, cuyos barcos se hundieron en épocas pasadas. ${ }^{4}$ La Diosa ha tenido que hacer reparaciones de emergencia para que sus palabras no naufraguen y teme que varios de los retazos puedan fallar al mismo tiempo. Ella no conoce del futuro. Por más que ha sido ensalzada por genios y doctos ${ }^{5}-$ lo que la

1. Algunas metáforas de este párrafo fueron escritas originalmente por Wilhelm Friedrich Nietzsche. Las citas que tienen lugar a continuación solo pueden tomarse como referencia acerca del sentido de los aforismos, ya que son frases usuales en diferentes partes de Así habló Zaratustra. Sobre el buen dormir, véase Nietzsche (2011a: 69-72).

2. Sobre el sentido de las carcajadas, véase Nietzsche (2011a: 343). Asimismo, sobre la comedia véase Nietzsche (2011b: 35). También véase Kant (2003: 259) .

3. Sobre las aguas profundas, véase Nietzsche (2011a: 180-184 y 202).

4. Una explicación sobre la diferencia entre estos elementos y la conveniencia de estudiar las ideas como enunciados se encuentra en Foucault (2010: 105-115).

5. Sobre los genios, véase Nietzsche (2011a: 236). Sobre los doctos, véase Nietzsche (2011a: 215-217). 
ha hecho ver como navegante de un costoso velero-, es una honrada señora insegura. Entre sus indecisiones, la de la voluntad libre es desastrosa e inmensa. ${ }^{6}$ Esta es una cuestión fundamental para el derecho penal porque, de lo contrario, ¿por qué se castiga?

Llegan noticias desde Fráncfort del Meno. Según Klaus Günther (2003: 263-265), en la sociedad occidental el castigo se basa en que el ser humano es responsable y, por lo tanto, en que actúa libremente. Además, la institución de la pena pareciera ser necesaria porque nadie se imagina vivir en una sociedad sin penas (Günther, 2003: 263-265). Por esto, se continúa creyendo en la libertad de acción y en la responsabilidad penal pese a que muchos dogmáticos han excluido (o casi) las palabras «libertad» $\mathrm{y}$ «culpa» de sus discursos (Günther, 2003). Como la definición del concepto es tan difícil y se quiere evitar la tentación de utilizar la metafísica, se dice lo siguiente:

Si un delincuente causa un daño típico y su violación no es justificada, no cometió un error inevitable, no puede excusarse y no se trataba de un enfermo mental, entonces es responsable bajo el derecho penal (Günther, 2003: 265).

Así resume Klaus Günther en una frase todo el discurso de la materia. Lo que es cierto es que la práctica penal funciona de acuerdo con esta premisa que espera (tal vez inútilmente) su demostración por las ciencias naturales, la psicología o, quizás, la neurociencia. Es por este motivo que entre los juristas se ha optado por una fundamentación normativa de la libertad. El contexto social cambia el contenido de la responsabilidad penal y sus fines. ${ }^{7}$ Más que la causalidad, son los principios y las reglas aplicables en una determinada sociedad los que permiten establecer si una persona puede ser imputada de un delito o no (Günther, 2003: 269). De hecho, las causas científicas por las que se comete un delito pueden ignorarse a la hora de imputar. Este sería el caso, verbigracia, de un delincuente que haya sido maltratado gravemente durante su infancia y todos los científicos, psicólogos y psiquiatras del mundo observaran que actuó «sin libertad» (Günther, 2003: 269). Si tenía la oportunidad de respetar el derecho según las normas penales, el juez tendrá que castigarlo. Por este motivo, aunque la libertad de acción no puede «describirse empíricamente», la responsabilidad penal se entiende fundamentada en el contexto normativo (Günther, 2003: 274-275).

Precisamente, la decisión del juez de imponer una pena es el resultado de cierta práctica social de atribuir delitos a los imputables que infringen los mandatos del

6. Sobre los indecisos, véase Nietzsche (2011a: 61).

7. En la década del treinta, Karl Larenz en el derecho civil y Richard Honig en el derecho penal desarrollaron esta idea que ha inspirado, entre otros, a Claus Roxin y a Günther Jakobs. Yesid Reyes Alvarado (1992: 934) dice: «El principio fundamental sobre el cual se edifica la teoría de la imputación objetiva fue formulado a comienzos del siglo XIX por Hegel». Al respecto, puede verse Jakobs (1994), Roxin (1997; 2013), Feijóo (2002) y Honig (2009). 
derecho penal en el marco de un contexto social. De esta forma, puede identificarse el concepto de delincuente: la sociedad hace responsables a los criminales porque los considera capaces de tomar la decisión de obedecer los mandatos del derecho penal en condiciones de normalidad, pero deciden no hacerlo (Günther, 2003: 271). Al contrario, no considera como delincuentes a los sujetos que no tuvieron la posibilidad de ejercer control sobre sí mismos al desobedecer el derecho: los inimputables (Günther, 2003: 271).

A la pregunta «¿A quiénes me es permitido castigar?», la Diosa de la Democracia responde:

- Las personas utilizan la noción de libertad inclusive si se ha demostrado que se trata de una ilusión. ¿Por qué no penar a los que fueron libres de respetar las normas que impongo y las desobedecen?

- ¿iLibres?

- Lo sé, lo sé... La ficción quedará redactada así: «Los libres son personas normales en circunstancias normales».

$-¿$ ¿Y cómo los vas a castigar?

- Bueno, en realidad no importa cómo en la medida en que la pena los trate como fines en sí mismos y no como objetos...

${ }_{-}^{\text {¡P} P e r o ~ q u e ́ ~ c o n t r a d i c c i o ́ n ! ~ ¡ E s a ~ e s t r e l l a ~ y a ~ s e ~ a p a g o ́ ! ~}$

${ }_{-}$¡Síl Pero sigue habiendo trasmundanos que se guían por su recuerdo. ${ }^{8}$

\section{¿Por qué debo castigar a los libres?}

Para hacer imputable a una persona de una conducta delictiva, debe satisfacerse el requisito de la libertad normativa, es decir, deben determinarse las normas del sistema jurídico que expresan las reglas que califican una conducta como delito para imponer a la postre un castigo merecido. Si la conducta que se estudia no fue libre, entonces se impone una medida de seguridad o se excluye la responsabilidad. Sin embargo, para que el castigo sea merecido, es necesario estudiar el contenido macro de la pena y su legitimación en el contexto de una sociedad en la que los seres humanos son considerados sujetos morales. Existen múltiples teorías de la pena y cada una de ellas defiende una finalidad o combinación de finalidades del castigo diferentes. Nietzsche ya decía con honestidad:

8. Sobre trasmundanos, véase Nietzsche (2011a: 73-77). Para entender la referencia a las estrellas: «Dos cosas llenan el ánimo de admiración y respeto, siempre nuevos y crecientes, cuanto más frecuencia y aplicación se ocupa de ellas la reflexión: el cielo estrellado que está sobre mí y la ley moral en mí» (Kant, 1951: 150). En relación con el imperativo categórico, Nietzsche (2011b: 28) responde: «Por fortuna aprendí pronto a separar el prejuicio teológico del prejuicio moral, y no busqué ya el origen del mal por detrás del mundo». 
En lo que se refiere $[. .$.$] a su sentido, ocurre que, en un estado muy tardío de la$ cultura [...], el concepto de pena no presenta ya de hecho un sentido único sino toda una síntesis de «sentidos» [...]. Hoy es imposible decir con precisión por qué se imponen propiamente penas (2011b: 115).

Volveremos sobre el punto, pero pese a esta indefinición de sentido, forzosamente se ha de aceptar que la pena se impone en el contexto de la comisión de un delito, es decir, como una respuesta a la infracción penal cometida por un ser humano libre. ${ }^{9}$

De otra parte, en los Estados seculares se debe explicar por qué es legítimo castigar a los delincuentes. ${ }^{10}$ En la actualidad, las soluciones a este problema tienden hacia una concepción de moralidad política (Günther, 2014: 3). Para Klaus Günther (2014: 4-7), esto implica el tratamiento como sujetos morales tanto de la víctima (cuyos derechos fueron negados) como del delincuente (sujeto responsable de la negación) y de la sociedad (conformada por seres receptores de un mensaje moral que los mantiene lejos de la tentación del delito). Así, la pena es una reacción proporcional al reproche de la conducta que expresa la condena moral (Günther, 2014: 6). Lo contrario, sería una infracción a la dignidad humana porque la víctima y el delincuente no serían considerados como fines en sí mismos. ${ }^{11}$ Esta es una opinión ampliamente difundida en el derecho penal. Por ejemplo, Heiko Lesch (1999: 11-18, 71 y 73) dice que, para no infringir esta máxima, la pena solo se puede imponer en virtud de la acción del delincuente y en la medida de su culpabilidad. Asimismo, Günther Jakobs (2003) lo manifiesta en términos muy claros:

El principio de culpabilidad significa que la culpabilidad es un presupuesto necesario de la legitimidad de la pena estatal. A su vez, la culpabilidad es el resultado de una imputación reprobatoria, en el sentido de que la defraudación que se ha producido viene motivada por la voluntad defectuosa de una persona. [...] Solo de esta manera puede evitarse la instrumentalización de la persona al imponer la pena. ${ }^{12}$

Además de esta premisa, actualmente existe una tendencia a sostener que el castigo no solo es impuesto como respuesta merecida a un sujeto moral que actúa cri-

9. Así, por ejemplo, Heiko Lesch (1999: 11-18, 71, 73) considera que la pena solo se puede imponer en respuesta a un hecho que ha perturbado el orden y para restablecerlo (principio de culpabilidad). Heiko Lesch (1999: 14) dice: «Lo seguro es que mediante la pena se causa un mal como reacción a la lesión de una regla jurídica».

10. Con esta preocupación de legitimidad - además de los autores mencionados en los siguientes párrafos- véase Hörnle (2015: 20-22). También Jakobs(2003: 12) dice: «Podemos partir de la base de que una pena inútil no puede legitimarse de ningún modo en un Estado secularizado».

11. Esto, siguiendo la máxima: «Obra de tal modo que uses la humanidad tanto en tu persona como en la persona de cualquier otro, siempre como un fin al mismo tiempo y nunca solamente como medio» (Kant, 2006: 115-116). Véase en A 66-67.

12. La opinión del autor es mucho más compleja. Véase infra en «¿Qué me legitima para castigar?». 
minalmente, sino que tanto la pena como el delito tienen una faceta comunicativa dirigida a la sociedad, al ofensor y a la víctima. ${ }^{13}$ De esta forma, la pena es "parte de una secuencia comunicativa que ya había comenzado con el delito» (Günther, 2014: 7) y, por lo tanto, es la respuesta merecida por el delincuente en virtud del mensaje que había enviado.

En el marco de este discurso - en el que la pena comunica y reprocha la culpabilidad del delincuente - ha surgido la teoría de la pena como censura. Esta postura, formulada por Andrew von Hirsch (1998: 31-40), sostiene que la pena se compone de una faceta normativa («censura») y una preventiva («sufrimiento» $\mathrm{o}$ «tratamiento duro»). En primer lugar, la faceta normativa de la pena es la desaprobación que recibe el infractor por parte de la sociedad al realizar una conducta prohibida. El infractor es receptor de este reproche debido a que es un ser moral, es decir, un ser capaz de entender la connotación negativa de sus actos. La censura es el elemento comunicativo de la pena y lo que permite diferenciar el castigo de otras formas de tratamiento severo. Este elemento tiene un sentido que es articulado en la sentencia y comunicado a agentes racionales. En segundo lugar, la faceta preventiva de la pena - que refuerza la censura- es la privación o sufrimiento que conlleva la sanción. Se trata de una regla prudencial que indica la no comisión de delitos por la amenaza penal y consiste en la «realización de algo», es decir, es la faceta visible de la pena (Günther, 2014: 5-6). Klaus Günther (2014: 16) hace una crítica contundente a esta última teoría: No concibe la comunicación del castigo, de suyo, como un acto comunicativo. Por esto, pregunta: ¿Por qué acudir a un castigo «doloroso o gravoso» y no a uno simbólico? (Günther, 2014: 14) Este autor es de la opinión de que no es necesario acudir a una acción adicional a la de comunicar la censura (Günther, 2014: 15). De hecho, considera que la prisión (el castigo por excelencia) «es una acción comunicativa de no-comunicación» (Günther, 2014: 16).

Por ahora, podemos concluir que actualmente se entiende que la pena tiene un carácter comunicativo frente a seres morales normales que, al haber cometido un delito pudiendo actuar de otra forma, merecen ser castigados y tratados como fines en sí mismos. Por lo tanto, el estudioso de la pena debiera preguntarse también por la forma en que se transmite el mensaje que responde al delito. Enseguida se explicará el asunto.

A la pregunta «¿por qué debiera castigar?», la Diosa de la Democracia responde: «Para comunicar que los delincuentes son culpables de infringir una norma penal».

13. "Crimen y castigo están en una relación comunicativa». Para más información, véase Günther (2014: 7) y Hörnle (2015: 33-44). 


\section{¿Cómo comunica el castigo?}

Como se ve, para que una persona pueda ser llamada «delincuente» debió haber infringido las normas del derecho penal libremente. Si lo hizo, el derecho le impondrá una pena que comunicará a la sociedad, a la víctima y al delincuente el reproche que le hace a este último. En la medida en que esta condena moral tendrá forma de mensaje, vamos a analizar en qué consiste y cómo funciona un acto que comunica.

Según Klaus Günther, «hablar es realizar acciones de acuerdo con reglas» y el acto comunicativo suele - de manera contingente y convencional- acompañarse de acciones extralingüísticas (por ejemplo, para elogiar a alguien puede entregársele un regalo) (Searle, 1991: 385; Günther, 2014: 16-20). ${ }^{14}$ Sin embargo, en el derecho existe una tendencia a no utilizar los actos extralingüísticos o simbólicos, todavía usuales, para darle efectos jurídicos a las instituciones (Günther, 2014: 16). ${ }^{15}$

Por otro lado, para la teoría del acto de habla (Habermas, 1991, 1992, 1996, 1998, 2003; Searle, 1991) la acción comunicativa tiene dos facetas (Günther, 2014: 18; Habermas, 1992: 370). El acto locutivo (locutionary act) y el acto ilocutivo (illocutionary act) (Searle, 1991: 372). El acto locutivo es la faceta formal o el simple pronunciamiento de las palabras, y expresa su «contenido proposicional superficial» (Searle, 1991: 372; Günther, 2014: 18). En contraste, el acto ilocutivo es la faceta que permite cumplir las reglas que le comunican la intención del emisor a los receptores (Günther, 2014: 18). A su vez, esta faceta de la acción comunicativa produce unos efectos perlocutivos (perlocutionary effect) y tiene una fuerza ilocutiva (illocutionary force) (Günther, 2014: 18; Habermas, 1992: 371). Los efectos perlocutivos (perlocutionary effect) son el producto, intencional o no, de lo que se expresa (Günther, 2014: 20) ${ }^{16}$ La fuerza ilocutiva es el sentido real e intencional de lo que declaran los interlocutores, los incorpora «en un contexto intersubjetivo que tiene una estructura normativa». ${ }^{17}$ De un contexto intersubjetivo sincero, surge la necesidad de dar razones y justificaciones; de la estructura normativa, la necesidad de considerar que tanto el ofensor como la víctima tienen el derecho a no estar de acuerdo, pero que deben explicar sus razones (Günther, 2014: 20).

14. Asimismo, se puede encontrar una explicación de la pena en un sentido comunicativo en Kindhäuser (2009) y Mañalich (2010: 175).

15. Este es el caso, verbigracia, de la promesa en derecho civil en la que ya no es necesaria alguna estricta solemnidad romana.

16. «Esto es más obvio con los actos explícitos ilocutivos que hacen uso de verbos performativos como "yo prometo»», de forma que se da a luz al compromiso. Por lo tanto, «cambian el mundo, especialmente el social (y moral)» (Günther, 2014: 18-19).

17. También, véase Habermas (1998: 375): «La teoría del discurso cuenta con la intersubjetividad de orden superior que representan los procesos de entendimiento que se efectúan a través de los procedimientos democráticos o en la red de comunicación de los espacios públicos políticos». 
Los hechos sociales institucionales, como la promesa o el matrimonio, tienen fuerza ilocutiva en la medida en que existen reglas extralingüísticas previas que sistematizan y dan un sentido que es reconocido y atribuido colectiva e intencionalmente por el grupo social. Lo anterior puede trasladarse al juicio penal si se considera la sentencia como un acto declarativo de habla que produce dos cambios en el mundo institucional: ${ }^{18}$ Reafirmar la validez de la norma violada y censurar el delito (Günther, 2014: 19). Sin embargo, esta postura solo tiene en cuenta la relación normativa que se crea con la sentencia e ignora la relación intersubjetiva entre el emisor y el receptor. La fuerza ilocutiva está determinada por el sincero y mutuo entendimiento entre estas dos personas y no solamente por el surgimiento del vínculo, de hecho, lo más importante es que lo que se exprese sea entendido y aceptado por ellas. A esto se le da el nombre de efecto general de vínculo (general binding effect) (Günther, 2014: 19), lo que no es exclusivo de los hechos institucionales, sino común a toda comunicación sincera (Günther, 2014: 19). En un debate de este tipo es posible el desacuerdo, pero este obliga a que el emisor y el receptor den sus razones. ${ }^{19} \mathrm{Al}$ darlas, se generan conclusiones y compromisos, un consenso que fortalece cada vez más el vínculo entre los participantes (Günther, 2014: 20).

Luego, el derecho penal se comunica con ellos para darles razones justificadas en los principios de la comunidad y conminarlos a actuar de una determinada manera (Günther, 2014: 13-14). Los ciudadanos son colegisladores en una sociedad participativa y deben ser considerados como sujetos deliberativos que pueden entender razones para dirigir sus intenciones y sus comportamientos. Estos sujetos siempre podrán proponer razones en contra de la legislación para invalidar la justificación mediante el procedimiento legislativo (Günther, 2014: 13). ${ }^{20}$ La legitimidad de las normas jurídicas reposa en que son el producto democrático de una deliberación a la que todos los ciudadanos tienen el derecho de participar — bien sea a través de las libertades de expresión y de información, o por medio de la elección de sus representantes

18. También —-para algunos- del delito: «Si el hecho punible es entendido como un hecho institucional cuyo valor declarativo consiste en la contradicción de una norma (de comportamiento), entonces el nivel de referencia de la pena jurídica ha de corresponderse con este modo de existencia institucional del hecho punible» (Mañalich, 2010: 173).

19. Existen tres motivos de desacuerdo que, en general, pueden versar sobre: «La verdad del contenido proposicional, así como de las afirmaciones implícitas y presupuestas sobre el contexto de los hechos del acto de habla; la exactitud [o certidumbre] del contenido normativo explícito del acto de habla; y, sobre la sinceridad y autenticidad de la realización del acto de habla [...]. Así, en un debate el interlocutor sostiene [...] la verdad de sus afirmaciones, la exactitud del componente normativo y la sinceridad del componente intersubjetivo» (Günther, 2014: 19).

20. Por otro lado, véase el llamado «principio «D»» de Habermas (1991: 101; 1998: 172): «Válidas son aquellas normas (y solo aquellas normas) a las que todos los que puedan verse afectados por ellas pudiesen prestar su asentimiento como participantes en discursos racionales». 
(Günther, 2014: 13-14; Hörnle, 2015: 23-26 y 33-44). ${ }^{21}$ El delito comunica el desacuerdo del delincuente con las razones de la ley penal a través de un medio ilegítimo - negándole a la víctima la posibilidad de colegislar-, en cambio, la pena comunica el rechazo de estas razones que niegan el derecho; tanto el delito como la pena le hablan a todos los miembros de la sociedad. Así, «se puede hablar, inclusive, de un círculo: El castigo se comunica con el ofensor, la víctima y la sociedad sobre las razones que justifican la legislación y las razones injustificadas del ofensor» (Günther, 2014: 14).

Por este motivo, Klaus Günther hace la crítica sobre el tratamiento duro que enunciamos más arriba. Siguiendo su planteamiento, ya no se hace hincapié en el componente declarativo de la imposición de la pena, sino en la validez discursiva del orden normativo, para la cual los ciudadanos son actores comunicativos responsables que se relacionan intersubjetivamente de forma sincera y como colegisladores. Es decir, el enfoque recae en el proceso penal - donde la sentencia es un acto comunicativo público y razonado- y ya no en la pena como tratamiento duro del delincuente, sino en la que este trato es contingente (Günther, 2014: 21-22). El delito es una declaración normativa de invalidez por parte del ofensor; la pena es el rechazo comunicativo de esta declaración por parte del derecho, cuyo actuar se legitima en el desconocimiento del carácter deliberativo y razonable de los ciudadanos (Günther, 2014: 22). Por esta razón, el derecho introduce al delincuente en un proceso penal, donde no será tratado como colegislador, sino solo como persona responsable con respecto a la norma que violó (Günther, 2014: 22).

A la postre, el delito es la expresión inadecuada del desacuerdo del criminal al que, por este motivo, se le somete a un proceso penal. Por un lado, la sentencia tiene la función de comunicar el reproche frente a la infracción y, por otro lado, la pena es la acción extralingüística que aún acompaña este mensaje. En la medida en que las reglas que establecen qué es lo normal y cómo se especifica la responsabilidad se definen a través del procedimiento democrático del cual el delincuente pudo formar parte, se le dejará de tratar, por un instante, como posiblemente deliberativo porque es merecidamente de derecho. El injusto que ha causado es contrario a la norma que pudo haber fabricado y es una tentativa de empujón a la normatividad democrática

21. Al respecto, Habermas (1998: 61): «También en las democracias establecidas las instituciones de la libertad existentes ya no permanecen inatacadas, si bien las poblaciones parecen exigir aquí más bien más democracia que menos. Sospecho, sin embargo, que el malestar y la inquietud tienen una raíz más profunda, a saber, el presentimiento y sospecha que, bajo el signo de una política completamente secularizada, el Estado de derecho no puede tenerse ni mantenerse sin democracia radical. Convertir este presentimiento en una idea es la meta de la presente investigación. En última instancia los sujetos jurídicos privados no podrán gozar de iguales libertades subjetivas si ellos mismos, en común ejercicio de su autonomía política, no se aclaran sobre intereses justificados y sobre criterios, y no se ponen de acuerdo sobre cuáles han de ser los aspectos relevantes bajo los que lo igual ha de tratarse de forma igual y lo desigual de forma desigual». 
que, pese a la mala intención del criminal, no cae al piso. El delincuente es sometido a un proceso y se le impone una pena porque le ha escuchado la víctima, y los demás miembros de la comunidad deben saber sobre el carácter mudo de su mensaje. Así - continúa la Diosa de la Democracia-, el delito es como si alguien hablara y yo, que soy la única que verdaderamente habla, voy a responderle con el castigo. De esta forma, nuestra Diosa replica a la pregunta «¿cómo comunica el castigo?».

\section{¿Qué me legitima para castigar?}

Ahora, concentrémonos en lo que ha sucedido con el principio de culpabilidad y la forma en que se ha interpretado su sentido para poder mantener las instituciones de la responsabilidad penal que conocemos. Para esto, hemos escogido estudiar la visión de Günther Jakobs y de Klaus Günther. El primero ha propuesto una explicación en la que el principio de dignidad humana mantiene un eje central en términos formales, pero no materiales; el segundo ha llevado la discusión de la responsabilidad al ámbito de la formación de las normas jurídicas. Ya veremos lo que tienen en común estas dos perspectivas.

Para Günther Jakobs el principio de culpabilidad y el mantenimiento del orden social se encuentran en el eje argumentativo del problema de los fines de la pena. ${ }^{22}$ Como vimos, para él también es necesario respetar el principio de culpabilidad para no instrumentalizar al hombre (Jakobs, 2003: 11-12). Sin embargo - dice-, no basta con que la pena respete este principio, sino que en un Estado secularizado la pena debe ser útil en alguna medida para mantener el orden social (Jakobs, 2003: 12). Por este motivo, los fines sociales deben estar limitados por la culpabilidad sin que este ajuste sea tan fuerte que haga inútil al mal penal (Jakobs, 2003: 12-13). Según este autor, existe un concepto de culpabilidad formal y otro de culpabilidad material. La culpabilidad formal consiste en la imposición de la pena a los sujetos que, siendo capaces de comunicar y entender mensajes, expresan por medio de un delito que la vida social debe desarrollarse de forma contraria a la establecida por las normas del ordenamiento (Jakobs, 2003: 44). Como el delincuente ha expresado que no es fiel a la norma, el castigo debe transmitir un mensaje en el sentido de que el comportamiento del delincuente «no es determinante» (Jakobs, 2003: 44). Por todo lo anterior, a los miembros de la sociedad que no tienen la capacidad de comunicar ni de recibir mensajes no se les debe aplicar una pena, sino un tratamiento (verbigracia, a los enajenados). Por el contrario, a los sujetos con capacidad comunicativa se les da el manejo de personas competentes y se les hace responsables en caso de cometer un delito (Jakobs, 2003: 43). La culpabilidad material, en cambio, depende de la legitimi-

22. Sobre la doctrina de la culpabilidad como fin en sí mismo, Jakobs (2003: 14) dice: «Es mi intención declarada plantearle algunas dificultades a dicha doctrina». 
dad de las normas del ordenamiento (Jakobs, 2003: 45). Esta legitimidad no se desprende de la autodeterminación del sujeto gobernado a respetar la norma, sino que el mismo orden social establece cuáles normas son legítimas y cuáles no (Jakobs, 2003: 47). Es decir, para que una norma pueda ser considerada como legítima debe ser el producto de los mecanismos que para esto disponga el orden social (Jakobs, 2003: 47). Pues, finalmente, la sociedad es una organización de la que la persona hace parte irremediablemente. ${ }^{23}$ Por lo tanto, si un ciudadano comete un delito, la comprensión social de su comportamiento es que se está autocontradiciendo (Jakobs, 2003: 47). En otras palabras, para ser una persona del ordenamiento se deben seguir sus reglas (Jakobs, 2003: 47). Por otro lado, para Günther Jakobs la libertad sí está relacionada con el principio de culpabilidad. Sin embargo, se trata de la autodeterminación de las esferas de organización propias dentro de un orden social que es administrado descentralizadamente. Démosle la palabra sobre este aspecto:

Bien es cierto que la culpabilidad está relacionada con la libertad, pero no la libertad de la voluntad, con el libre albedrío, sino con la libertad de autodeterminarse, esto es, el administrar la cabeza y el ámbito de organización propios. La culpabilidad solo es posible en un orden en el que no todos los procesos son dirigidos de manera centralizada, es decir, que es administrado descentralizadamente (Jakobs, 2003: 55).

Esta explicación describe la forma en que el sistema, en efecto, instrumentaliza al ser humano para mantener el orden social, sin embargo, como él mismo aclara, a una explicación no se le puede reprochar el infringir la máxima de la dignidad humana (Jakobs, 2003: 48-49).

Por otro lado, para Klaus Günther (2003: 274) «la tradición cristiana, en particular la noción de conciencia ha jugado un rol importante en la formación de una arquitectura mental». Por este motivo, el concepto de libertad se sigue utilizando en la práctica jurídica, de forma que el castigo confirma públicamente la necesidad de autocontrol que justifica la función normalizadora de la responsabilidad (Günther, 2003: 273-274). Según él, y como venimos de decir, para no instrumentalizar a la víctima ni al delincuente debe dárseles tratamiento de seres morales con capacidad de dar y comprender razones (Günther, 2014: 4-7). Dado que con el castigo se comunican razones fundamentadas en las normas de responsabilidad penal, entonces es necesario explicar en qué medida estas normas son legítimas en una sociedad democrática (Günther, 2003: 275). En una sociedad de este tipo, los ciudadanos del Estado han sido doblemente codificados (doppelt codiert) porque son, al mismo tiempo,

23. «Pero si en realidad no se considera seriamente la posibilidad de permanecer en el estado natural, las pretensiones de modificar el contenido del orden solo pueden realizarse a través de los procedimientos previstos para ello, lo que a su vez significa: solo dentro del orden, y no renegado de él» (Jakobs, 2003: 47). 
autores y destinatarios de las normas jurídicas (Günther, 1994: 155; 2003: 275-276). Las personas deliberativas son sujetos que tienen el derecho de dar y aceptar razones sobre la validez de las normas que les gobiernan (Habermas, 2003: 189), así como la capacidad de tomar una posición crítica frente a las conductas y manifestaciones propias y ajenas. ${ }^{24}$ Como ciudadanos son responsables de darse sus normas porque estas ya no se fundamentan en la autoridad de Dios ni en la tradición, sino en la deliberación (Günther, 2003: 276). El contenido particular de deliberación es relativo al nivel real de participación, pero esta responsabilidad se trata de un presupuesto básico para que un ciudadano pueda considerarse a sí mismo como tal (la denominada «autocomprensión») (Günther, 2003: 276). Asimismo, al tratarse de un presupuesto, la sociedad debe garantizar la existencia de los procedimientos que permitan la materialización del ejercicio de sus derechos, sin embargo, los ciudadanos no tienen el deber de ejercerlos (Habermas, 2003: 189). En cambio, las normas producto de la deliberación democrática se dirigen a ellos como personas de derecho e implican un deber de obediencia siempre y cuando tengan la capacidad de apartarse de ellas (Günther, 1994: 156; 2003: 276). A contrario sensu, en la medida en que el delincuente, durante la comisión del delito, hubiese podido haber seguido la norma quebrantada, entonces se comportó culpablemente (Günther, 1994: 156). No importa el porqué las personas de derecho se motivan a obedecer las normas jurídicas porque si los ciudadanos pueden reconocerse entre ellos como colegisladores, entonces no pueden desconocerlas (Günther, 2003: 276). Al haber podido participar en el proceso de formación de las normas jurídicas (como ciudadanos) y tener la capacidad de tomar una posición crítica frente a las acciones y manifestaciones propias y ajenas (como personas de derecho), la culpabilidad de los delincuentes se deriva de la doble condición de ciudadano y persona de derecho, y no de la autocontradicción del ciudadano (Günther, 1994: 154-156). Por este motivo, Klaus Günther (2003: 275) dice que «deberíamos responsabilizarnos en las formas en que especificamos la responsabilidad».

Como se puede apreciar, sin embargo, los dos caminos conducen al mismo destino: la culpabilidad y la libertad tienen una función normalizadora o, en términos similares, una finalidad de mantenimiento del orden social. Para Günther Jakobs la culpabilidad es una forma de autodeterminarse en un orden administrado descentralizadamente, es decir, la libertad de las personas competentes consiste en poder administrar el ámbito de organización propio conforme a lo establecido por el mecanismo legítimo en un orden social determinado. En cambio, para Klaus Günther los ciudadanos se reconocen recíprocamente como colegisladores de un orden social democrático en el que se garantiza el presupuesto (no obligatorio) de su participación y en el que la libertad de las personas de derecho consiste en poderse comportar

24. Para una mayor comprensión de los conceptos de ciudadano, persona deliberativa y persona de derecho, véase Günther (1999). 
conforme a las (obligatorias) normas legítimas. En el límite, los delincuentes deben ser tratados como sujetos responsables, es decir, como personas competentes o de derecho. La legitimidad de las normas se desprende de lo que determinen los mecanismos que para esto dispone el orden social, esto es, que sean un producto deliberativo. Por consiguiente, se puede deducir que el concepto de libertad en derecho penal tiene la finalidad de mantener la normalidad del orden democrático. ${ }^{25}$

\section{Paseo vespertino: Castigo, libertad y filosofía moral}

\section{Acerca de la idea «la pena comunica» $y$ «el hombre es libre»}

En la actualidad, existe una tendencia que sostiene que el origen del elemento comunicativo de la pena podría identificarse en la filosofía del derecho de Immanuel Kant y de Georg Wilhelm Friedrich Hegel, sin ser propiamente teorías comunicativas de la pena. ${ }^{26}$ Estas dos visiones marcaron la tradición del derecho penal contemporáneo ${ }^{27}$

25. Actualmente, hay otras posturas sobre la libertad y la culpabilidad en el derecho penal, pero nos hemos concentrado en las dos anteriores porque se preocupan especialmente por explicar la legitimidad de las normas jurídicas. Entre las otras posturas se encuentra la inspirada por la filosofía de Joseph Raz que sostiene que las normas penales son motivos para no actuar de los destinatarios de la norma, es decir, que son razones excluyentes para la acción. Sin embargo, según esta postura, existe una «relativa independencia que las normas exhiben con respecto a las razones que hablan a favor de su validez» $y$ se admite que es necesario para la imputación de un comportamiento «que el destinatario de la norma haya estado en posición de formarse la intención, en atención a la norma, de evitar intencionalmente el comportamiento antinormativo». Debido a estas dos afirmaciones y por cuestiones de espacio, hemos decidido estudiar con más profundidad las teorías que precisamente ven la legitimidad de las normas como centro del problema en cuestión y que limitan el concepto de libertad a una función normalizadora o de administración de las esferas propias y no desde el punto de vista de las «razones para actuar». Para más información, véase Mañalich (2010: 174, 179 y 180). En sentido similar, pero inspirado en doctrinas del siglo XVIII: «El juicio de imputación de segundo nivel [el de primer nivel es una adscripción de la conducta al sujeto moral que pudo actuar] también expresa acerca de la libertad con la que obró el autor. Si nos circunscribimos a la imputación de hechos antijurídicos a la culpabilidad, la imputación de segundo nivel significa el juicio por el cual se considera que obró con conocimiento de la antijuridicidad de su hecho, por una parte, tuvo motivo para emitir la acción prohibida o para ejecutar la acción prescrita y, por otra parte, no tuvo ningún contramotivo comprensible que le impidiera el cumplimiento de su deber» (Hruschka, 1994: 351). Esta postura se fundamenta en la diferencia entre normas de comportamiento y las reglas de imputación. También puede consultarse Kindhäuser (2009). Adicionalmente, sobre un concepto de culpabilidad fuertemente inspirado en la filosofía kantiana, véase Zaczyk (2010a).

26. «Se pueden encontrar concepciones del delito como una acción comunicativa entre las teorías retribucionistas de la pena, incluyendo tal vez a Kant y a Hegel. Aunque ninguna de estas trabajó sobre una teoría comunicativa de la pena en sentido estricto, entendieron el crimen y el castigo como una secuencia estructurada por el significado de la acción más allá de la intención del delincuente» (Günther, 2014: 8).

27. Por ejemplo, véase Jakobs (1995; 2004), Zaczyk (2010b) y Hörnle (2015). 
y su estudio nos permite identificar que la idea de «la pena comunica» está ligada desde sus orígenes a la idea de «el ser humano es libre». Ambas - como explicamos en el apartado anterior- siguen vigentes en nuestros sistemas penales. Según Klaus Günther, el delito es una acción que comunica algo más que la intención del delincuente, similar a lo que ya se sugería en los textos de Kant y Hegel: el delito es una negación del criminal porque «si robas, te robas a ti mismo». ${ }^{28}$

La presentación tradicional de la teoría de la pena de Kant dice que el castigo es una forma de retribución de la culpabilidad del delincuente. ${ }^{29}$ Así, la pena se impone de manera retrospectiva, en respuesta al delito y al que sea necesario restablecer el orden perturbado (Kant, 2008: 166). Es decir, el delito niega la justicia ${ }^{30} \mathrm{y}$, por lo tanto, debe imponerse una pena que en principio siga la ley del talión. ${ }^{31} \mathrm{Y}$ es que como para Kant el ser humano no puede ser tenido como instrumento para el bienestar de los demás («el ser humano es un fin en sí mismo»), no es posible fundamentar la pena en

28. «Si le injurias, te injurias a ti mismo; si le robas, te robas a ti mismo; si le pegas, te pegas a ti mismo; si le matas, te matas a ti mismo» (Kant, 2008: 167; Günther, 2014: 8). «La vulneración que afecta al delincuente no es solo justa en sí - como justa es, a la vez, su voluntad, que es en sí y la existencia de su libertad, el derecho-, sino que también es un derecho impuesto en el delincuente mismo, esto es, en su voluntad existente, en su acción. Porque en su acción, como acción de un ente racional, está implícito un universal: el que por medio de ella esté instituida una ley, a la que el delincuente ha reconocido por sí, y bajo la cual puede ser asumido, como bajo su derecho» (Hegel, 1968: 108). Para más información, véase en el $\$ 100$.

29. No obstante, en contraposición a esta presentación tradicional, se ha dicho que Kant no excluía la posibilidad de fundamentar la pena solamente en razones de provecho (sin excluirlas) (Hörnle, 2015: 24). Esto se dice a partir de la cita directa del texto: El castigo «no puede nunca servir simplemente como medio para fomentar otro bien, sea para el delincuente mismo sea para la sociedad civil, sino que ha de imponérsele [sin embargo] solo porque ha delinquido» (las cursivas son nuestras) (Kant, 2008: 166). Como se puede ver de la lectura completa de la frase en cuestión, la calificación de la teoría como «absoluta» resulta más coherente. Así ya lo interpretaba Schopenhauer (2001: 112), quien criticaba la máxima de la siguiente forma: «A la hora de formular su imperativo categórico Kant utilizó este aserto: «se debe tratar siempre al hombre como fin y nunca como medio», y los kantianos no se han cansado de repetirlo, pues la gente en general adopta gustosamente principios que le dispensan de cualquier reflexión ulterior. La frase no deja de sonar rimbombantemente bondadosa y tampoco falta a la verdad. Solo que, examinada con algún detenimiento, expresa la regla de nuestro comportamiento [...] de un modo muy indirecto, vago e indeterminado y a la hora de aplicarla, hemos de aportar aclaraciones, modificaciones, determinaciones particulares para cada caso en concreto, puesto que su carácter universalista resulta insuficiente y deja lugar a la duda».

30. Dice Kant (2008: 170): «Por consiguiente, todos los criminales que han cometido el asesinato, o también los que lo hayan ordenado o han estado implicados en él, han de sufrir también la muerte; así lo quiere la justicia como idea del poder judicial, según leyes universales, fundamentadas a priori».

31. «Solo la ley del talión (ius talionis) puede ofrecer con seguridad la cualidad y cantidad del castigo, pero bien entendido en el seno del tribunal (no en tu juicio privado); todos los demás fluctúan de un lado a otro y no pueden adecuarse al dictamen de la pura y estricta justicia, porque se inmiscuyen otras consideraciones» (Kant, 2008: 167). 
razón a beneficios o ventajas que puedan desprenderse de esta (Kant, 2006: 115-116).32 La ley penal es un imperativo categórico de carácter universal y la ausencia de castigo es inadmisible. ${ }^{33}$ Según Klaus Günther, allí podrían verse rasgos del elemento comunicativo de la pena: ${ }^{34} \mathrm{El}$ delincuente, al violar la norma, expresa libremente y de forma universal una negación de la seguridad y de la efectividad de la norma poniendo en peligro a la comunidad (Günther, 2014: 9).35

Por otro lado, para Hegel el delito no es la mera violación a la ley pública, sino la materialización de la negación de una norma defectuosa enunciada por el delincuente (Günther, 2014: 10-11). Para Klaus Günther, en Hegel también se podría rastrear el carácter comunicativo de la pena. ${ }^{36} \mathrm{El}$ delincuente, con la comisión del delito y por ser un agente responsable, expresa que puede negar voluntariamente la vigencia de una norma (Günther, 2014: 11). La pena, por el contrario, objeta esta violación como inválida y restablece la vigencia de la norma. Solo así, los demás miembros de la sociedad pueden seguir orientándose a partir de ella (Günther, 2014: 11). La pena no se impone por la inseguridad que provoca el delito, sino porque el delincuente afirma la validez de una norma defectuosa, verbigracia «matar está permitido». La afirmación del criminal debe ser tomada en serio porque comunica a otras personas la validez general de la norma que enuncia. Sin embargo, esta norma solamente es válida para él y, por lo tanto, es falsamente universal: el derecho no puede tolerar excepciones de una norma de carácter general. Esto constituiría una negación de la justicia en sí misma porque el derecho se fundamenta en el respeto de los demás como personas.

En los próximos dos subtítulos daremos noticia de estas teorías que, al ser parte de sistemas filosóficos amplios, requieren para su comprensión de una mirada más integral que la típica referencia a los pasajes relativos a la teoría de la pena. El método que utilizaremos para nuestro examen es la exégesis. El lector encontrará al comienzo de cada sección una cita directa de las teorías de la pena de los autores en cuestión

32. Sobre la pena en particular, véase Kant (2008: 166-167). Véase en A66 y 67.

33. «La ley penal es un imperativo categórico y jay de aquel que se arrastra por las sinuosidades de la doctrina de la felicidad para encontrar algo que le exonere del castigo o incluso solamente de un grado del mismo, por la ventaja que promete, siguiendo la divisa farisaica «es mejor que un hombre muera a que perezca todo el pueblo»!» (Kant, 2008: 167).

34. «El castigo articula el sentido implícito público del acto criminal del delincuente, que fue en sí mismo comunicativo. Hacer insegura la vida y la propiedad podría ser interpretada como una regresión al estado de naturaleza» (Günther, 2014: 9).

35. A su vez: «Son delitos públicos fabricar o cambiar dinero falso, el hurto, la rapiña, etcétera, porque de este modo se pone en peligro a la comunidad y no solo a una persona individual» (Kant, 2008: 166).

36. De opinión similar es Mañalich (2010: 179): «Pues la toma de posición personal del autor [del delito] que es jurídico-penalmente relevante radica exclusivamente en el no-seguimiento de una norma vinculante para él. Dicho con Hegel: desde el punto de vista del derecho, el quebrantamiento del derecho no tiene existencia positiva, sino puramente negativa». 
y - en seguida - una explicación de estas a partir de algunos conceptos básicos de sus sistemas filosóficos. Esto nos permitirá entender la relación entre delito-penalibertad de una forma más profunda y comparar lo sostenido por los autores con algunas tendencias del derecho penal actual.

\section{Pena y libertad en Immanuel Kant ${ }^{37}$}

Démosle la palabra al filósofo de Königsberg en primer lugar:

Decir [al momento de pactar el contrato social] que quiero ser castigado si asesino no significa sino decir que me someto junto con todos los demás a las leyes penales [...]. Yo, como colegislador que decreta la ley penal, no puedo ser la misma persona que, como súbdito, es castigada según la ley; porque como tal, es decir, como criminal, no puedo tener un voto en la legislación (el legislador es santo). Por tanto, cuando yo formulo una ley penal contra mí, como criminal, es la razón pura jurídico-legisladora en mí (homo noumenon) la que me somete a la ley penal a mí, como capaz de cometer crímenes, por consiguiente, como otra persona (homo phaenomenon) junto con todas las demás en una asociación civil (Kant, 2008: 171)..38

¿Qué significa que «la razón pura jurídico-legisladora» somete a un ser «capaz de cometer crímenes»? A continuación, nos referiremos al compatibilismo kantiano entre la doctrina de la moralidad y la doctrina de la naturaleza que es, cómo veremos en este ensayo, el centro de la cuestión.

Idealismo trascendental es el nombre que Kant (2003: 22) le da en la Crítica de la razón pura a la teoría según la cual los seres humanos no tenemos la posibilidad de conocer las cosas en sí mismas, sino que solo podemos experimentar representaciones fenoménicas. ${ }^{39}$ Las representaciones fenoménicas se identifican con una cosa en sí pero no tienen existencia, en cuanto representaciones, por fuera de nosotros mismos (Kant, 2003: 22 y 437).$^{40}$ Además, según él, existen formas de intuición puras y empíricas. Las formas de intuición puras son el espacio y el tiempo, y aunque no son ideas puras - pues solo existen para los seres humanos (Kant, 2003: 82) 41 $^{4}$ sí son previas

37. Para una visión general del pensamiento kantiano, véase Rohlf (2018).

38. Sobre los problemas que representa esta explicación dualista del ser humano y una reinterpretación de la filosofía kantiana para argumentar la prohibición de la pena de muerte a partir de la imposibilidad práctica de dicho dualismo, véase Zaczyk (2010b: 111-131).

39. Véase en BXIX-XX. Al respecto y mayoritariamente de forma crítica, véase Westphal (1991), Hoyos (2003: 229), McWherter (2016), Saunders (2016) y Rohlf (2018). Asimismo, sobre la importancia del idealismo trascendental en su época, lo que llevó a Kant a tener importantes seguidores. Véase Paulsen (1902: 96 y 97).

40. Véase en BXIX-XX y A491/B519. Al respecto, véase Hoyos (2003: 229), McWherter (2016: 198) y Rohlf (2018).

41. Véase en A42/B59. Al respecto, véase Westphal (1991: 134) y McWherter (2016: 196). 
a toda percepción efectiva (Kant, 2003: 82).42 Por el contrario, la forma de intuición empírica depende enteramente de la sensibilidad (Kant, 2003: 82). ${ }^{43} \mathrm{~A}$ su vez, los elementos de todo conocimiento humano son la intuición y los conceptos, que también pueden ser puros o empíricos. Las intuiciones y los conceptos puros «solo son posibles a priori» y las intuiciones y los conceptos empíricos «únicamente los son $a$ posteriori» (Kant, 2003: 93). ${ }^{44}$ Mantengamos estas premisas presentes porque son los principios críticos que permiten a Kant (2003: 27) reconciliar la moral y el derecho con las ciencias de la naturaleza. ${ }^{45}$

Como el ser humano solo puede experimentar representaciones fenoménicas por medio de sus sentidos, Kant (2003: 24) considera que existe un riesgo de que, por medio del uso de la razón especulativa o de la observación empírica, se suprima «el uso puro (práctico) de la razón». ${ }^{46}$ En otras palabras, como la experiencia no nos permite llegar a la comprensión de los fenómenos morales al no existir objetos de la intuición empírica que nos permitan percibir tales apariencias, existe el peligro de que se prescinda de ellos (Kant, 2003: 45). ${ }^{47}$ Por este motivo, es necesario que el uso puro práctico de la razón vaya «más allá de los límites de la sensibilidad» y supere los problemas que podría enfrentar si se le estudiara a través de la intuición empírica (Kant, 2003: 24). ${ }^{48}$ Para esto, parte de la premisa de que aunque las cosas en sí mismas son incognoscibles, siempre es posible pensarlas (Kant, 2003: 25). ${ }^{49} \mathrm{Si}$ se considerara la existencia de Dios, la inmortalidad del alma y la libertad como fenómenos entonces tendrían que estar sometidas a las leyes de la naturaleza, sin embargo, no pueden demostrarse conforme a estas..$^{50}$ En cambio, si se las considera en tanto cosas en sí mismas, es posible pensar que no están sometidas a las leyes de la naturaleza porque no podemos conocerlas por medio de la intuición empírica (Kant, 2003: 25). ${ }^{51}$ Así, en

42. Véase en $\mathrm{A}_{42}-\mathrm{A}_{43} / \mathrm{B}_{59}-\mathrm{B} 60$.

43. Véase en $\mathrm{A}_{42}-\mathrm{A}_{43} / \mathrm{B} 59-\mathrm{B} 60$.

44. Véase en $A 51 / B 75$.

45. Véase en BXXX. Al respecto, véase Westphal (1991: 134 y ss). Esta es una de las temáticas más problemáticas de la Crítica de la razón pura. Hay quienes sostienen que según Kant existen dos mundos, el de las cosas en sí y el de las representaciones fenoménicas, y quienes consideran que se trata de un solo mundo. Una explicación general se encuentra en Rohlf (2018). Esta problemática también es abordada por Foucault (2018: 256), quien contrapone a Kant con los ideólogos. El presente ensayo no versa específicamente sobre la citada problemática y explicar cuál es nuestra posición tendría que realizarse en otro espacio. Para nuestra finalidad, por el contrario, basta con tener claro cuáles son los principios críticos con base a los cuales surgió la discusión.

46. Véase en BXXV. Al respecto, véase Westphal (1991: 134).

47. Véase en $A_{3} / B 7$. Al respecto, véase Westphal (1991: 134).

48. Véase en BXXV. Al respecto, véase Westphal (1991: 134).

49. Véase en BXXVI.

50. Al respecto, véase Westphal (1991: 135). También véase Saunders (2016: 164).

51. Véase en BXXVIII. 
la medida en que estas ideas sean posibles como cosas en sí -aunque no podamos explicar cómo son posibles-, no existe contradicción alguna entre las ciencias de la naturaleza y la moral (Kant, 2003: 27).52 A eso se refiere la famosa de Kant (2003: 27) que dice:

Tuve, pues, que suprimir el saber para dejar sitio a la fe; y el dogmatismo de la metafísica, es decir, el prejuicio de que se puede avanzar en ella sin una crítica a la razón pura constituye la verdadera fuente de toda incredulidad, siempre muy dogmática, que se opone a la moralidad. ${ }^{53}$

Advertimos que hemos descartado el estudio de cómo Kant justifica en específico la existencia de Dios y la inmortalidad del Alma, ya que no son útiles en este espacio. ${ }^{54}$ Por el contrario, hemos profundizado acerca del concepto de libertad que, como hemos dicho, es un concepto central de la teoría del derecho y de la pena. En la Crítica de la razón pura Kant advierte una «antinomia de la libertad» (Kant, 2003).55 La contradicción consiste - siguiendo con lo expuesto sobre el idealismo trascendental- en que, si solo se aceptara la causalidad por leyes de la naturaleza, entonces no podría haber libertad de acción (Smith, 1986: 126). A lo cual responde que como la causalidad por leyes de la naturaleza sería un regreso ad infinitum y, de hecho, esta forma de causalidad se fundamenta «en que nada ocurre sin causa suficiente[mente] determinada a priori», entonces hay que asumir - lo que él llama - una «absoluta espontaneidad causal» (Kant, 2003: 408)..$^{66}$ En la Fundamentación para una metafísica de las costumbres lo dice nuevamente. ${ }^{57}$ No cabe explicar cómo es posible la libertad según las leyes de la naturaleza porque es una mera idea (Kant, 2006: 158)..$^{8}$ Es decir, solo podemos asumirla como una posibilidad y como un presupuesto (Kant, 2006: $142-143)^{59}$ de los sujetos que creen «tener conciencia de una voluntad» (Kant, 2006). ${ }^{60}$

Nuestro conocimiento sensible de la libertad como realidad de la naturaleza es imposible porque no existe un fenómeno externo «libertad» al cual podamos acceder

52. Véase en BXXIX.

53. Véase en BXXX.

54. Al respecto, véase Westphal (1991: 135).

55. Véase en A446/B474-A447/B475. Para más información, véase Smith (1986: 126), Westphal (1991: 134), Sedgwick (1996: 582), Sedgwick (2010: 48-49) y Carlson (2013: 162).

56. «Solo nosotros [los seres humanos] poseemos una forma de «causalidad moral», o la capacidad de «espontaneidad» que escapa a la naturaleza» (Smith, 1986: 126).

57. El idealismo trascendental también se expresa en esta obra, no es exclusivo de la Critica de la razón pura. Para más información, véase Kant (2006: 146). Véase en A105-106.

58. Véase en A120-121. Al respecto, véase Westphal (1991: 137).

59. Al respecto, véase Westphal (1991: 137).

6o. Véase en A121. 
por medio de la intuición empírica (Smith, 1986: 128; Kant, 2006: 146). ${ }^{61}$ Sin embargo, si el ser humano es un ser racional al que le es posible percibir su existencia empírica por medio de la sensación interna y —según el idealismo trascendental- se debe admitir que toda percepción tiene una identidad con una cosa en sí misma, entonces existe un sí mismo del mundo inteligible (Kant, 2006: 148). ${ }^{62}$ Para Kant, la existencia empírica se encuentra sustentada por la ley de la naturaleza, pero a la existencia inteligible le gobiernan las leyes de la razón $n^{63} \mathrm{y}$, desde esta perspectiva en particular, su acción no es provocada por la causalidad, sino por la idea de la libertad. ${ }^{64}$ Por este motivo, solo desde el aspecto inteligible las acciones son acordes a la autonomía de la voluntad, en cambio, desde la perspectiva empírica, las acciones son producto de los apetitos y las inclinaciones y, por tanto, son conformes a la heteronomía de la voluntad (Kant, 2006: 150). ${ }^{65}$ Una división absoluta entre el aspecto de lo sensible (phaenomenon) y el de lo inteligible (noumenon) es imposible porque siempre tiene que existir una cosa en sí misma a la que le corresponda una representación y, así, estas perspectivas no son incompatibles (Kant, 2006: 148-149) ${ }^{66}$ Kant (2006: 150-151) dice todo lo contrario:

Mas como el mundo inteligible entraña el fundamento del mundo sensible y por ende también las leyes del mismo, dicho mundo intelectual supone una instancia legislativa inmediata con respecto a mi voluntad (que pertenece por entero al mundo inteligible) y también ha de ser pensado como tal, con la cual habré de reconocerme en cuanto inteligencia, aunque por otra parte me reconozca como un ser que pertenece al mundo sensible, sometido a la ley del primero, esto es, a la razón, que alberga

\section{Véase en A105-106.}

62. Véase en A108.

63. «Por ello un ser racional [...] posee dos puntos de vista [...] primero en tanto que pertenece al mundo sensible y está bajo las leyes naturales (heteronomía), segundo como perteneciente al mundo inteligible, bajo leyes que, independientes de la naturaleza, no son empíricas, sino que se fundan simplemente en la razón» (Kant, 2006: 148-149). Véase en A108-109.

64. «Como un ser racional, que pertenece al mundo inteligible, el hombre nunca puede pensar la causalidad de su propia voluntad sino bajo la idea de la libertad pues la independencia de las causas determinantes del mundo sensible (independencia que la razón ha de atribuirse siempre a sí misma) es la libertad. Con la idea de la libertad está indisociablemente unido el concepto de autonomía, pero con este se asocia ese principio universal de la moralidad que sustenta en aquella idea todas las acciones de seres racionales, tal como la ley de la naturaleza sustenta todos los fenómenos. [...] Pues ahora vemos que, cuando nos pensamos como libres, nos trasladamos al mundo inteligible como miembros de él y reconocemos la autonomía de la voluntad, junto con su corolario, que es la moralidad; pero cuando nos pensamos como sometidos al deber, nos consideramos como pertenecientes al mundo sensible y a la vez, sin embargo, como miembros de un mundo inteligible» (Kant, 2006: 149). Véase en A109. Al respecto, véase Carlson (2013: 162-163).

65. Véase en A111. Al respecto, véase Westphal (1991: 136).

66. Véase en A108-109. 
esta ley en la idea de la libertad, y por lo tanto como sometido a la autonomía de la voluntad; por consiguiente, las leyes del mundo inteligible han de ser consideradas como imperativos para mí y las acciones adecuadas a este principio tienen que ser vistas como deberes. ${ }^{67}$

Como se ve, el sujeto empírico está sometido al imperativo del sujeto inteligible. ${ }^{68}$ Para Kant (2006: 97), los mandatos de la razón se expresan en forma de imperativos categóricos e imponen obligaciones válidas universalmente. ${ }^{69}$ Por esto, se las considera causas objetivas que determinan la voluntad de los sujetos a realizar acciones llamadas «buenas» (Kant, 2006: 92). ${ }^{70}$ Las leyes expresadas en mandatos de la razón pura práctica son incondicionales y necesarias, es decir, son categóricas (Kant, 2006: 103). ${ }^{71}$ Pero el sujeto no solo se ve influido por máximas universalmente válidas, sino que también actúa conforme a causas subjetivas que le proporcionan felicidad o agrado (Kant, 2006: 92). ${ }^{72}$ Esto parece una contradicción, en cuanto la voluntad del sujeto se ve determinada por causas necesarias y universales, y también por inclinaciones particulares que constituyen excepciones (Kant, 2006: 109). ${ }^{73}$ Pero para Kant no se trata de una contradicción, sino de una resistencia empírica contingente. ${ }^{74}$ La validez del imperativo categórico no se deriva en absoluto de las particularidades empíricas del sujeto porque esto impediría su universalidad..$^{75}$ Por el contrario, el imperativo categórico se encuentra relacionado con la voluntad de todo ser racional y la Metafísica de las costumbres es la encargada de descubrir el deber ser (Kant, 2006: 112). ${ }^{76}$

Ahora estamos en condiciones de entender a qué se refieren los términos homo noumenon y homo phaenomenon de la cita de la Metafísica de las costumbres sobre la que trata este apartado. ¿Cómo es posible que se diga que la razón pura jurídicolegisladora somete al ser empírico a la ley penal? Kant —en su diálogo con Beccaria

67. Véase en A110-A111.

68. Al respecto, véase Westphal (1991: 135).

69. Véase en A43-44 Asimismo, véase Kant (2006: 104). Véase en A51 y 52. Al respecto, Westphal (1991: $138)$.

70. Véase en $\mathrm{A}_{37}$ y 28.

71. Véase en A50.

72. Véase en A38. Al respecto, véase Westphal (1991: 149).

73. Véase en A58.

74. «Por consiguiente, todo cuanto sea empírico no solo es algo totalmente inservible como suplemento del principio de moralidad, sino que se muestra sumamente perjudicial para la pureza misma de las costumbres, en las cuales el valor intrínseco de una voluntad absolutamente buena queda realzado por encima de cualquier precio y consiste precisamente en que el principio de la acción se vea libre del influjo ejercido por fundamentos contingentes que sólo puede suministrar la experiencia» (Kant, 2006: 111).

75. El deber ser no puede ser buscado en el mundo empírico sino «exclusivamente a priori en los conceptos de la razón pura» (Kant, 2006: 56).

76. Véase en A62. 
acerca de la pena de muerte- aclara quién comete el delito y debe ser castigado: el ser empírico. Como venimos de decir, el sujeto königsberguense está determinado por el dualismo entre homo noumenon y homo phaenomenon. ${ }^{77}$ De este modo, el ser humano puede comprenderse a partir de sus causas naturales (phaenomenon) y como un ser independiente de la causalidad, esto es, como un sujeto moral (noumenon). En el primer caso, como un ser empírico que actúa conforme a sus inclinaciones, independientemente del mandato de la razón, y en el segundo asumiendo la razón pura jurídico-legisladora como justificación de la acción..$^{78}$ Así, al que se condena con la pena no puede ser el sujeto inteligible que - como tal- solo podría actuar según la autonomía de la voluntad pura, es decir, conforme al principio supremo de la moralidad. ${ }^{79}$ En cambio, la pena se impone al sujeto empírico porque su acción corresponde a sus tentaciones e inclinaciones - actúa conforme al principio de la felicidad $-y$ ha quebrantado el imperativo categórico de la ley penal. ${ }^{80}$ De esta manera, para imputar responsabilidad, el sujeto que actuó tuvo que haber sido libre de seguir sus inclinaciones ${ }^{81} \mathrm{y}$, por consiguiente, se puede decir que la responsabilidad penal kantiana se fundamenta en la existencia de una voluntad práctica (en contraposición a una voluntad inteligible) ${ }^{82}$

Cuando enunciamos en qué consistía la teoría de la pena de Kant dijimos que -según la interpretación de Klaus Günther- el delincuente expresa libre y universalmente una negación de la seguridad y de la efectividad de la norma poniendo en

77. Esta diferenciación se encuentra en múltiples apartados de la Metafísica de las costumbres. Véase en particular Kant (2008: 51, 122, 171, 276, 292, 297-298). Al respecto, véase Hoyos (2003: 234), Zaczyk (2010a: 183), Zaczyk (2010b: 129). Sobre el término «königsberguense» que utilizo: «Una palabra todavía contra Kant como moralista. Una virtud tiene que ser invención nuestra, personalísima defensa y necesidad nuestra: en todo otro sentido es meramente un peligro. Lo que no es condición de nuestra vida la daña: una virtud practicada meramente por un sentimiento de respeto al concepto «virtud», tal como Kant lo quería, es dañosa. La «virtud», el «deber», el «bien en sí», el bien entendido como un carácter de impersonalidad y de validez universal - ficciones cerebrales en que se expresan la decadencia, el agotamiento último de las fuerzas de la vida, la chinería königsberguense» (Nietzsche, 1996: 35). Véase en $\$ 11$.

78. Al respecto, véase Hoyos (2003: 335).

79. «Las primeras [las acciones como miembro del mundo inteligible] se basarían en el supremo principio de la moralidad, las segundas en el de la felicidad» (Kant, 2006: 150). Véase en A111-112.

80. «Si fuese únicamente [un ser inteligible], todas mis acciones serían siempre conformes a la autonomía de la voluntad, mas como quiera que me intuyo al mismo tiempo como miembro del mundo sensible, deben ser conformes a dicha autonomía» (Kant, 2006: 150). Véase en A111.

81. Al respecto, véase Hoyos (2003: 229).

82. «Este «deber ser» categórico representa una proposición sintética a priori, toda vez que sobre mi voluntad afectada por apetitos sensibles se añade todavía la idea de esa misma voluntad, pero pura en cuanto pertenece al mundo inteligible, la idea de una voluntad práctica por sí misma que contiene, según la razón, la suprema condición de aquella otra voluntad afectada por los apetitos sensibles [...]» (Kant, 2006: 150). Véase A111-112. 
peligro a la comunidad. ¿Pero a qué se debe este peligro? En Kant la libertad es previa a la fundación de la república. Sin embargo, solo por medio del pacto de unión civil se puede garantizar que el arbitrio de uno se coordine con el del otro (Kant, 2008: 3940). En esto consiste la ¡ley universal! del derecho: «Obra externamente de tal modo que el uso libre de tu arbitrio pueda coexistir con la libertad de cada uno» (Kant, 2008: 40). Así, en virtud del carácter externo de la acción, no puede haber derecho ni libertad sin coacción. ${ }^{83}$ Es más, para que el contrato social sea legítimo debe respetarse el principio de libertad de todos los ciudadanos, lo que impone la necesidad de que cada uno respete las esferas ajenas (Kant, 2008: 84) ${ }^{84}$ Con el derecho público, ${ }^{85}$ los tribunales garantizan dicha interacción a través de la justicia distributiva. ${ }^{86} \mathrm{La}$ acción del delincuente se puede entender, por consiguiente, como una amenaza a la libertad de los demás ciudadanos y, por lo tanto, como una oposición al estado jurídico que garantiza su interacción. Parafraseando, el delito vulnera la posibilidad de interacción entre ciudadanos libres y la pena se impone incondicionalmente porque en el Estado jurídico es inadmisible dicha vulneración. A contrario sensu, la pena se impone por la seguridad de las interacciones de los ciudadanos en el Estado jurídico. ${ }^{87}$ Esto es ¡ley universal!

\section{Pena y libertad en Georg Wilhelm Friedrich Hegel}

Continuemos con Hegel (1968: 106):

La primera violencia como poder ejercitado por el ser libre y que viola la existencia de la libertad en su significado concreto, el Derecho en cuanto Derecho, constituye el delito; el juicio negativamente infinito en su pleno significado [...], por el cual se niega no solo lo particular, la asunción de una cosa bajo mi voluntad [...], sino, a la vez, lo universal, lo infinito en el predicado de mío, la capacidad jurídica, es decir, sin la intervención de mi opinión [...] y justamente contra ella; todo esto constituye la esfera del derecho penal. ${ }^{88}$

\footnotetext{
83. Al respecto, véase Hoyos (2004: 201) y Zaczyk (2010a).

84. Al respecto, véase Hoyos (2004: 202).

85. «El conjunto de leyes que precisan ser universalmente promulgadas para producir un Estado jurídico es el derecho público» (Kant, 2008: 139).

86. «Del derecho privado en el estado de naturaleza surge, entonces, el postulado del derecho público: en una situación de coexistencia inevitable con todos los demás, debes pasar de aquel estado a un estado jurídico, es decir, a un estado de justicia distributiva» (Kant, 2008: 137).

87. «Significa que quien roba hace insegura la propiedad de todos los demás; por lo tanto, se priva a si mismo (según la ley del talión) de la seguridad de toda posible propiedad; nada tiene y tampoco puede adquirir nada, pero, sin embargo, quiere vivir, lo cual es imposible si otros no le sustentan» (Kant, 2008: 168).

88. Véase en $\$ 95$.
} 
La teoría de la pena hegeliana podría resumirse en que la pena es el restablecimiento del derecho en cuanto derecho (Hegel, 1968: 99-101) ${ }^{89}$ Sin embargo, en nuestra opinión no se puede exponer tan someramente su teoría. Por el contrario, planteémonos una de las primeras preguntas que surgen de la lectura de la cita: ¿Cómo puede una primera violencia de un ser libre negar la libertad en su significado concreto? Para dar respuesta a este interrogante, debemos explorar qué es la libertad para Hegel. El punto de partida que hemos escogido es su oposición al formalismo kantiano que, como veremos, desemboca en su Filosofía del derecho.

Recordemos que Kant fundamenta la posibilidad de la libertad y, con ello, una idea central de la moral y el derecho a través del idealismo trascendental. Si la identidad entre lo empírico y lo inteligible se refutara, ¿qué consecuencias tendría para la moral y el derecho? Según Hegel, Kant logró demostrar la unidad entre lo inteligible y lo empírico solo formalmente. ${ }^{90}$ La Crítica había procurado dejar sentado que toda representación fenoménica tiene su identidad con una cosa en sí, pero esto solo demuestra la estructura por la cual se puede hablar de una unidad y deja sin contenido al imperativo categórico (Smith, 1986: 125). La cosa en sí no es más que una abstracción no esencial del fenómeno que, por el contrario, es una multiplicidad (Hegel, 1979: 29). Así, en Kant existe un enfrentamiento entre la unidad pura ideal y la realidad empírica múltiple, lo que niega dicha unidad (Hegel, 1979: 29). En contraposición, Hegel (1979: 30-31) es de la opinión de que como dicha diferenciación no proviene del fenómeno mismo, entre lo ideal y lo real hay una «identidad absoluta». ${ }^{11}$ En otras palabras, en realidad el fenómeno es una unidad absoluta - no meramente formal- de ambos (Hegel, 1979: 29). Por este motivo, la razón pura jurídico-legisladora kantiana no podría establecer el deber ser. Esto, porque la ley de la razón pura práctica solo podría expresarse a través de proposiciones analíticas si se pretendiera la validez universal de sus máximas (Smith, 1986: 126; Sedgwick, 1996: 564) y, como el mundo práctico está lleno de particularidades, esto es lógicamente imposible..$^{22}$

89. Véase en $₫ 99-101$.

90. «En lo que se llama la razón práctica, solo hay que conocer, por tanto, la idea formal de la identidad de lo ideal y lo real, y en estos sistemas, esta idea debería constituir el punto de la indiferencia absoluta» (Hegel, 1979: 29). Para más información, véase Smith (1986), Habermas (1991), Westphal (1991), Houlgate (1995), Sedgwick (1996), López Hernández (2000), Díaz (2004) y Sedgwick (2010). En contra de esta crítica suele decirse que la filosofía kantiana no puede reducirse a la filosofía a la fundamentación de la metafísica de las costumbres. Al respecto, véase Sedgwick (2010: 46).

91. En su Filosofía del derecho diría: «Lo que es racional es real; y lo que es real es racional» (Hegel, 1968: 34). Esta locución ha desembocado en múltiples críticas a su sistema. Al respecto, véase Franco (1997) y Pawlik (2005).

92. «Pero la materia de la máxima sigue siendo lo que es, una determineidad o una singularidad; y la universalidad que le da acogida en la forma, constituye también una unidad analítica a secas; pero si se expresa en una proposición pura la unidad que se le confiere como lo que es, entonces la proposición 
El argumento es el siguiente: $\mathrm{Si}$ - según opinión de Kant- el razonamiento puro práctico se caracteriza por ser la abstracción de todo contenido al ser una unidad pura ideal y universalmente válida, entonces el deber ser derivado de la razón pura práctica es esencialmente vacío y no podría regir el mundo real que es múltiple y lleno de contenido (Hegel, 1979: 35; Smith, 1986: 126-127; Sedgwick, 1996: 565 y ss.). Hegel (1979: 35) lo dice expresamente así: «Buscar una legislación ética, pues, dado que debería tener un contenido, según la razón práctica absoluta, su esencia consiste en no tener contenido».

Paralelamente, esta objeción le permite a Hegel llegar a la conclusión de que el formalismo kantiano también sustrae de contenido a la libertad porque si la identidad entre la voluntad práctica y la voluntad pura se basa en una unidad meramente formal, entonces el ser sensible no es realmente libre. ${ }^{93}$ En otras palabras, Kant hace un excesivo énfasis en la faceta inteligible y pura de la libertad, por consiguiente, en un concepto sin contenido de voluntad (Smith, 1986: 125). Por esto, para Kant «lo bueno» es lo que es determinado por la causa objetiva de la libertad pura, negándole la posibilidad de la autonomía de la voluntad a las acciones externas (Smith, 1986: 126; Sedgwick; 1996: 582; Westphal, 1991: 148). Esta crítica al pensamiento kantiano desemboca en una preocupación central en la Filosofía del derecho de Hegel ${ }^{94} \mathrm{y}$, aun-

o bien es analítica o constituye una tautología» (Hegel: 1979, 34). «Típicamente, los comentaristas defensores de la ética kantiana contra la objeción de Hegel del «formalismo vacío» argumentan que Hegel tergiversa en su análisis la demostración de la aplicación del imperativo categórico y que además imputa erradamente a Kant una visión de deberes específicos derivados analíticamente de él. Típicamente, son culpables de no considerar las objeciones hegelianas en el contexto de su proyecto de proponer una alternativa al idealismo kantiano» (Sedgwick, 1996: 563).

93. «Entonces resulta que se trata de la abstracción absoluta de toda materia de la voluntad: mediante un contenido se pone una heteronomía del libre arbitrio. Pero precisamente ahora el interés radica en saber qué sean, pues, derecho y deber; se pregunta conforme al contenido de la ley ética, pero únicamente se actúa a causa de este contenido; sin embargo, la esencia de la voluntad pura y de la razón pura práctica, consiste en que se abstraiga todo contenido, resultando entonces contradictorio en sí» (Hegel, 1979: 35).

94. En la Enciclopedia se puede leer: «La voluntad libre efectivamente real es la unidad del espíritu teorético y práctico» (Hegel, 2005: 519). Véase en $\$ 481$. Asimismo, el primer parágrafo de la Filosofía del derecho hace alusión a la mencionada objeción: «La filosofía trata de ideas y, sin embargo, no de las que se suelen llamar meros conceptos, porque más bien demuestra su unilateralidad y su falsedad, así como que el concepto (no lo que frecuentemente se entiende designar como tal y que sólo es una abstracta determinación intelectiva), es lo que únicamente tiene realidad, es decir, en el modo de darse él mismo tal realidad. Todo lo que no sea esa realidad, presentada por medio del concepto mismo, es existencia transitoria, contingencia externa, opinión, apariencia inesencial, falsedad, ilusión, etcétera. La configuración que toma para sí el concepto en su realización, constituye, para el conocimiento del concepto mismo, el momento esencial de la Idea, diferente de la forma del ser sólo como concepto» (Hegel, 1968: 39). Véase en $\$ 1$. Asimismo, trata en específico la controversia en el $\$ 135$. Véase Houlgate (1995: 859) y Sedgwick (1996: 566). 
que no es la única de las objeciones que le hace, sí es la que más nos interesa en este ensayo. ${ }^{95}$ Esto, porque partiendo de la objeción expuesta, se puede decir que la responsabilidad penal kantiana se fundamenta en un concepto vacío de libertad (Hegel, 1979: 35). Así, conviene preguntarnos: ¿Cuál sería entonces un proyecto en el que la libertad no se abstraiga de contenido?

Precisamente, la realización de la idea de la libertad es el objeto de la Filosofía del derecho hegeliana. ${ }^{6}$ Pero debemos descartar el estudio completo de las tres etapas en las que esto se explica — que son el derecho abstracto, la moralidad y la eticidadporque nuestra atención está volcada hacia la relación delito-pena y, por consiguiente, haremos exclusivamente las referencias relevantes para la comprensión sistemática de esta. La teoría de la pena de Hegel se encuentra expuesta en la primera parte de su Filosofía del derecho, que lleva el nombre de derecho abstracto. Allí se estudia la personalidad jurídica, la propiedad y el contrato como instituciones que implican la libertad en un sentido abstracto o de realidad inmediata (Hegel, 1968). ${ }^{97}$ Por lo tanto, estas instituciones no son la materialización de la libertad, pero sí deben ser protegidas del injusto (Hegel, 2005: 529). ${ }^{98}$

Para Hegel (2005), el injusto es una apariencia de derecho consistente en la antítesis del derecho en sí..$^{99} \mathrm{~A}$ su vez, el injusto penal es el enfrentamiento de la voluntad maliciosa particular y el derecho en sí, ${ }^{100}$ pero como el derecho en sí mismo es un absoluto, entonces no puede ser nunca verdaderamente negado y, por lo tanto, el delito es una apariencia $n u l a .{ }^{101}$ Como se ve con estas frases sintéticas y cortas, para entender la teoría de la pena de Hegel es necesario aclarar múltiples aspectos. Para él, el crimen es una acción de un ser racional que provoca una lesión que tiene una existencia externa, por ejemplo, la muerte, y una existencia interna que perturba el derecho en cuanto derecho. ${ }^{102}$ El resarcimiento de la lesión externa es tarea del derecho de da-

95. Según Habermas, las objeciones más importantes se refieren al universalismo kantiano, la impotencia del deber ser, el terrorismo de la pura intención y el formalismo (Habermas, 1991: 98-99).

96. «El campo del derecho es, en general, la espiritualidad y su próximo lugar y punto de partida es la voluntad, que es libre, de suerte que la libertad constituye su substancia y su determinación; y el sistema del derecho es el reino de la libertad realizada, el mundo del Espíritu, expresado por sí mismo, como en una segunda naturaleza» (Hegel, 1968: 46). Véase en $\$ 4$. Al respecto, véase Pawlik (2005: 26 y 27).

97. Véase en $\$ 33-104$.

98. Véase en $₫ 496$.

99. Véase en $\$ 496$. También véase Hegel (1968: 101). Véase en $\$ 82$. Al respecto, véase Oppenheimer (1913: 207).

100. «Finalmente, en tanto la voluntad particular se enfrenta al derecho-en-sí, tanto con la negación de este como con la negación de su reconocimiento o apariencia [...], esta voluntad es voluntad maliciosa que ejerce violencia, [esto es] que comete un delito» (Hegel, 2005: 530-531). Véase en $₫ 499$.

101. Al respecto, véase Oppenheimer (1913: 207-208).

102. «La vulneración del derecho como tal es, ciertamente, una existencia positiva, exterior, que es en sí nula. La manifestación de su nulidad es el anulamiento de la existencia de aquella vulneración; es 
ños y la anulación de la lesión interna es tarea del derecho penal. ${ }^{103}$ Con el castigo se niega la vigencia general de la voluntad del delincuente, cuyas acciones - en cuanto ser racional- tienen apariencia de universalidad (Hegel, 1968) ${ }^{104}$ Por el contrario, la ausencia de pena provocaría la inaceptable vigencia general de la voluntad particular del delincuente (Hegel, 1968). ${ }^{105}$ Para Hegel, la responsabilidad es el correlato de la libertad personal que tienen los seres racionales y, por consiguiente, la pena es una manifestación de la racionalidad del delincuente. ${ }^{106} \mathrm{El}$ derecho es entonces un absoluto y el delito solamente es una fase de su desarrollo (Hegel, 1968). ${ }^{107}$ En otras palabras, la pena «es la realidad del derecho como su necesidad que se concilia consigo misma mediante la negación de su vulneración» (Hegel, 1968). ${ }^{108}$ Por otro lado, con la anulación externa del delito (con la imposición de la pena) se puede seguir tomando la «norma quebrantada como modelo de orientación para el propio comportamiento» (Lesch, 1999: 34). En otras palabras, la imposición de la pena impide un «efecto dañoso para la realidad empírico social» (Lesch, 1999: 34) y si el Estado no fuera el titular de la persecución penal, la víctima respondería vengativamente en contra de lo acontecido y habría una sucesión infinita de venganzas (Lesch, 1999: 35-36).

Pero la relación entre el delito y la pena no se abarca completamente con la expli-

la realidad del derecho como su necesidad que se concilia consigo misma mediante la negación de su vulneración» (Hegel, 1968: 106). Véase en $\$ 97$.

103. «La vulneración, solamente en la existencia externa o en la posesión, es un mal y un daño a cualquier género de propiedad o de bienes; la negación de la vulneración, en tanto es perjuicio, constituye la satisfacción civil como resarcimiento, en cuanto esto puede tener lugar, en general» (Hegel, 1968). Véase en $\$ 98$. «Empero, la vulneración con la cual es afectada la voluntad que es en sí (es decir, con respecto a la voluntad de aquel que viola, así como a la del vulnerado y de los demás), no tiene existencia positiva en esa voluntad, que como tal es en sí, como tampoco en el simple producto. Por sí, esta voluntad que es en si (derecho, Ley en sí), es, más bien, lo exteriormente no existente y, a este respecto, inviolable. La vulneración, para la voluntad particular del ofendido y de los demás, es sólo algo negativo. La existencia positiva de la vulneración es solo en cuanto voluntad individual del delincuente. La vulneración de esta voluntad en cuanto existente es la anulación del delito, que de otro modo sería válido; es el restablecimiento del derecho» (Hegel, 1968). Véase en $₫ 99$.

104. Véase en $\$ 99$.

105. Véase en $\$ 99$.

106. «Por otra parte, no es únicamente el concepto del delito, su racionalidad en sí y por sí, con o sin el consenso de los individuos, lo que el Estado debe hacer válido, sino la racionalidad formal, el querer del individuo, que está implícito en la acción del delincuente. Como ser racional, el delincuente es honrado con la pena, que es mantenida como continente de su derecho particular. Este honor no llega a él si el concepto y la norma de su pena no se toman de su mismo acto y si es considerado el delincuente como un animal dañino al que habría que hacer inofensivo, o a los fines de la intimidación y de la corrección» (Hegel, 1968). Véase en $\$ 100$. Al respecto: «La libertad sin responsabilidad no es realmente verdadera libertad personal, sino mero arbitrio subjetivo» (Lesch, 1999: 31). También en Houlgate (1995: 872).

107. Véase en $\$ 97$.

108. Véase en $₫ 97$. 
cación del injusto porque el crimen es, además, violencia de una voluntad malicio$s a{ }^{109}$ Esto implica que la apariencia de derecho expresada por el delincuente a través del delito es querida (Hegel, 2005: 530). ${ }^{110}$ Por esto, nos es relevante un comentario adicional acerca de la teoría de la acción en Hegel. Esta se estudia en la segunda estancia del derecho, que lleva el nombre de moralidad. Con Kant decíamos que la acción buena y moral está determinada por la ley universal del sujeto inteligible. Sin embargo, para Hegel (1979: 35) la acción sucede en circunstancias reales y, por lo tanto, es compleja y rica en contenido, y no puede ser gobernada por el vacío e inteligible imperativo categórico. ${ }^{111} \mathrm{Si}$ el deber ser ya no se puede explicar a través de leyes universales y vacías, ¿entonces qué significa que la voluntad del delincuente sea maliciosa?

Para Hegel (2005: 533), el derecho se funda en la autodeterminación del individuo libre ${ }^{112} \mathrm{y}$-dada la identidad absoluta entre lo real y lo ideal— la acción del ser humano de carne y hueso puede ser orientada libremente hacia lo moral sin referencia a un mundo inteligible. ${ }^{113}$ En otras palabras, el sujeto empírico es uno y el mismo sujeto inteligible. ${ }^{114}$ Por esto, la voluntad subjetiva se determina interiormente por particularidades de la razón de la voluntad hacia lo ético (Hegel, 2005: 533). ${ }^{115}$ Así, el deber ser es una prescripción interna que le permite al ser humano aprobar y reconocer espontáneamente tanto lo bueno como lo malo (Hegel, 1968: 130 y 134; 2005: 533).116 La intención está esencialmente dirigida hacia lo universal, abstracto y ético, pero en cuanto la voluntad se concreta exteriormente a través de la acción empírica también se hacen esenciales los aspectos particulares (como el bienestar propio) (Hegel, 2005:

109. «Pero si la apariencia de derecho es querida en cuanto tal por la voluntad particular en contra del derecho-en-sí, haciéndose así maliciosa la voluntad, el reconocimiento externo del derecho queda entonces separado de su valor y solo aquel se respeta, mientras este queda lesionado» (Hegel, 2005: 530). Véase en $\$ 498$.

110. Véase en $₫ 498$.

111. Sobre lo acá dicho: «Todo ejemplo real de acción es complejo de forma que no puede ser manejado por un imperativo categórico» (Westphal, 1991. 157).

112. «Pero en realidad, sin embargo, el derecho y todas sus determinaciones se fundan únicamente en la personalidad libre, es decir, en una autodeterminación que es más bien lo contrario de la determinación natural» (Hegel, 2005: 532). Véase en $\$ 502$.

113. Véase en $\$ 503$.

114. «Puesto que la satisfacción subjetiva del individuo mismo (incluso su reconocimiento en el honor y la gloria) está contenida en la realización de los fines que valen en sí y por sí; así la pretensión de que esto aparezca sólo en cuanto querido y alcanzado, como la opinión de que los fines objetivos y subjetivos se excluyen recíprocamente en la voluntad, es una afirmación vacía del intelecto abstracto» (Hegel: 1968, 124). Véase en: $\$ 124$.

115. Véase en $\$ 503$.

116. Véase en $₫ 132, \S 137$ y $\$ 503$. Al respecto, Houlgate (1995: 873). 
535). ${ }^{117}$ En otras palabras, el sujeto - en cuanto ser racional - tiene acceso al conocimiento de la «cualidad universal de la acción», pero cuando actúa se manifiesta el «ánimo determinante de la acción», es decir, «el derecho del sujeto de encontrar en la acción su satisfacción» (Hegel, 1968: 123). ${ }^{118}$ Por ello, pueden resultar dos esencialidades de la intención ${ }^{119}$ o dos conciencias: ${ }^{120}$ una «verdadera» dirigida hacia lo bueno en y por sí, y otra «formal» orientada hacia lo particular. ${ }^{121}$ Las intenciones, a su vez, pueden contradecirse entre sí, por lo que el deber del sujeto es exteriorizar su voluntad hacia el bien en y para sí, hacia lo universal. Dicho de otro modo, dirigir su acción hacia la realización del derecho, que no es otra cosa que el bienestar de los otros y la realización de la idea de la libertad (Hegel, 1968: 126 y 132; 2005: 535). ${ }^{122}$ Por esto, la acción del sujeto puede o no ser conforme a los fines esenciales (Hegel, 1968: 126) y cuando el agente exterioriza su voluntad hacia lo particular en desmedro de lo universal (que es por él conocido), se puede decir que actúa maliciosamente. Asimismo, como el agente se dirige hacia una intención no ética (no universal), entonces su acción es una apariencia de universalidad. ${ }^{123}$ Por todo esto, el delito es una apariencia provocada por una voluntad maliciosa que niega el derecho per se, es decir, niega la realización de la idea de la libertad y, con ello, el bienestar de los otros.

Por otro lado, si la acción humana está dirigida por intenciones entonces la conducta solo puede entenderse desde una perspectiva teleológica (Westphal, 1991: 148). Los fines o motivos concretos de la conducta tienen un sentido dadas sus circunstancias sociales y solo en atención a esto es posible establecer que una acción le pertenece a un ser humano libre (Hegel, 1968: 119). ${ }^{124}$ Además, la acción tiene múltiples consecuencias en el mundo y no todas ellas son obra de la voluntad del sujeto que actúa. Por esto, hay que diferenciar entre las consecuencias necesarias y las accidentales

117. Véase en $₫ 506$.

118. Las citas son del $\$ 120$ y 121. Véase también el $\$ 123$.

119. Esta es la nomenclatura en la Enciclopedia, véase Hegel (2005: 535). Véase en $\$$ 506. Véase también en Hegel (1968: 122, 132). Además, véase en $\$ 119$ y $\$ 134$. Al respecto Oppenheimer (1913: 206-207) y Franco (1997: 839, 847, 848).

120. Esta es la nomenclatura en la Filosofía del derecho. Véase Hegel (1968: 134). Véase en $₫ 137$.

121. Al respecto, Oppenheimer (1913: 206-207) y Franco (1997: 839, 847 y 848).

122. Véase en $\$ 125,134$ y 137. Véase en $\$ 507$. También: «El sujeto debe ser la dialéctica que decide una conexión entre ellas, excluyendo otras y suprimiendo su valor absoluto» (Hegel, 2005: 536), \$508. Al respecto, véase Houlgate (1995: 870) y Franco (1997: 839, 847, 848).

123. «Pero el sujeto no es solo algo generalmente particular en su existencia, sino que es también una forma de su existencia el ser certeza abstracta de sí mismo, reflexión abstracta de la libertad hacía sí misma. Por ello el sujeto es distinto de la razón de la voluntad y es capaz de convertir lo universal mismo en algo particular y de este modo convertirlo en apariencia. El bien ha sido así puesto como algo contingente para el sujeto y este, habiéndose decidido según lo dicho por algo opuesto al bien, puede ser malo» (Hegel, 2005: 536-537). Véase en $\$ 509$. Al respecto, véase Houlgate (1995: 871).

124. Véase en $\$ 115$. Al respecto, véase Reyes Alvarado (1992: 934). 
que se provocan con ocasión de la acción (Hegel, 1968: 120). ${ }^{125}$ Las consecuencias accidentales son las que sobrevienen de forma contingente, como no-queridas, es decir, como producto de la mera causalidad o del azar y no de la voluntad. ${ }^{126}$ Por el contrario, los propósitos de la acción implican la representación (o el conocer) de los fines ${ }^{127}$ y, así, solo las consecuencias representadas y queridas por el sujeto le son imputables. ${ }^{128}$ Por todo lo anterior, para poder decir que la acción del delincuente es maliciosa, esta tiene que ser dirigida por el querer y el conocer del sujeto hacia una intención particular en contra del derecho en sí. ${ }^{129}$ De esta forma, se puede interpretar que la acción del delincuente es obra suya y que, por lo tanto, se hace merecedor del castigo. Es más, como ser racional, el castigo es su derecho (Hegel, 1968: 108). ${ }^{130}$

Sin embargo, para Hegel el mundo debe garantizar las condiciones para que la acción buena sea posible y que la mala sea eliminada. ${ }^{131}$ Es decir, con Hegel la libertad no es un mero formalismo, sino que es una idea que se ha de realizar en el mundo. Por esto, para que la voluntad del agente pueda estar guiada espontáneamente hacia

125. $\$ 118$. Al respecto, véase Reyes Alvarado (1992: 934).

126. «Debe reconocerse como un aporte crucial al derecho penal la afirmación hegeliana de que a una persona solo le puede ser imputado aquello que constituya su obra, y no aquello que sea resultado de la simple causalidad, de la mala suerte o del destino» (Reyes Alvarado, 1992: 934).

127. «La voluntad en ejercicio por su propia virtud, incluye en su fin, enderezado al existir actual, la representación de las circunstancias del mismo. Pero, ya que la voluntad, a causa de esa previa suposición, es finita, la apariencia objetiva es accidental para ella y puede contener en sí algo distinto de lo que está en su representación. Pero el derecho de la voluntad es solo reconocer su propio acto, como acción propia y solo ser culpable de lo que ella conoce que de sus presuposiciones hay en su fin; de aquello que de ellas estaba implícito en su propósito. El acto puede ser imputado solo como culpa de la voluntad, como el derecho del saber» (Hegel, 1968: 119-120). Véase en $₫$ 117. También en Hegel (2005: 533). Véase en $\$ 503$. Al respecto, Reyes Alvarado (1992: 953).

128. En la filosofía del derecho penal se discute si esta afirmación hace que la teoría de la acción hegeliana solo sea aplicable a las conductas dolosas. Según Reyes Alvarado (1992: 953), es posible interpretarlo de manera más amplia, es decir, incluyendo los delitos imprudentes.

129. Sobre el nexo entre esta afirmación y la objeción de Hegel a Kant que explicamos en este texto, véase Houlgate (1995: 860).

130. Véase en $₫ 100$.

131. «La objetividad exterior, igualmente con arreglo a la distinción ya considerada de la voluntad subjetiva [...], constituye el otro extremo autosuficiente, un mundo para sí en sentido propio y opuesto a las determinaciones internas de la voluntad. Por ello es contingente que este mundo concuerde con los fines subjetivos, que el bien se realice [o no] en el mundo y que el mal, siendo como es el fin en y para sí nulo, se anule [también] en el mundo; [es contingente] además que el sujeto halle su bienestar en el mundo y [lo es también] por último que el sujeto bueno sea feliz en él y el sujeto malo sea desgraciado. Pero también al mismo tiempo, el mundo debe permitir que se lleve a cabo lo esencial, debe permitir que la buena acción llegue a buen término en él, del mismo modo que debe garantizar la satisfacción de su interés particular al sujeto bueno, impedírselo al malo y eliminar al mal mismo» (Hegel, 2005: 537). Véase en $\$ 510$. 
el bien per se es necesario que la vida ética le enseñe al sujeto hacia donde debe dirigir su voluntad (Hegel, 1968: 154-155). ${ }^{132}$ El presupuesto para esto es la personalidad jurídica (derecho abstracto) (Hegel, 1968: 41), ${ }^{133}$ pero su realización solo es posible en la tercera estancia dialéctica de la realización del derecho, que lleva el nombre de eticidad: "Ética es el concepto de la libertad convertido en mundo existente y naturaleza de la conciencia de sí misma» (Hegel, 1968: 151). ${ }^{134}$ Por este motivo, desde una perspectiva meramente abstracta, el deber «puede aparecer como limitación» de la subjetividad, pero desde la vida ética el deber es la liberación del individuo que deja de estar guiado por sus instintos, «se emancipa y alcanza la libertad sustancial» (Hegel, 1968: 152-153). ${ }^{135}$ Recordemos que esta era la idea central de la Filosofía del derecho: La libertad no es un concepto vacío, sino lleno de contenido. Por otro lado, el sujeto virtuoso es quien cumple los mandatos de respeto del derecho abstracto (Hegel, 1968: 153). ${ }^{136} \mathrm{~A}$ su vez, estos deberes son llenados de determineidades a través de la vida ética, es decir, en comunidad es donde «el habito de lo ético se convierte en segunda naturaleza» (Hegel, 1968: 154). ${ }^{137}$ Dicho de otro modo, el sujeto que actúa no es el homo phaenomenon sometido al indeterminado imperativo categórico impuesto por el trascendental homo noumenon, sino que el ser humano es un sujeto en cuyo mundo tiene la posibilidad de conocer el bien y realizar la libertad sustancial. Por lo tanto, el delincuente que pertenece a este mundo ha de ser castigado.

Con la vida ética, los mandatos se llenan de contenido y:

La sustancialidad ética alcanza, de este modo, su derecho y este, su validez; por lo cual, el arbitrio y la conciencia particular del individuo, que era por sí y constituía una antítesis con respecto a la sustancialidad, han desaparecido en ella; ya que el carácter ético reconoce como su fin motor a lo universal inmóvil pero abierto en sus determinaciones a la racionalidad real; y conoce también su dignidad y toda existencia de los fines particulares como fundada realmente en él. La subjetividad misma es la forma absoluta y la realidad existente de la sustancia; y la distinción entre el sujeto y aquella, como su objeto, fin y fuerza, solamente es la diferencia de la forma que a la vez ha desaparecido inmediatamente (Hegel, 1968: 154-155). ${ }^{138}$

132. Véase en $\$ 151-153$. Sobre la libertad y el estado de necesidad en relación con lo acá dicho sobre Hegel, véase James (2012).

133. Véase en $₫ 3$.

134. Véase en $\$ 142$. Al respecto, véase Houlgate (1995: 875).

135. Véase en $\$ 149$.

136. Véase en $\$ 150$.

137. Véase en $₫ 151$. Al respecto, véase Wood (1991: 370).

138. Véase en $\$ 152$. En nuestra opinión, la locura y la cuestión del castigo están íntimamente relacionadas y esto es particularmente evidente en una genealogía de la moral. Por este motivo, aunque este ensayo no versa específicamente sobre la primera problemática, encontramos conveniente realizar una referencia en cuanto a este punto. Pese a la relevancia de la prisión como forma de sanción, en el 
Es por esto por lo que el delito es un injusto provocado por un sujeto en cuyo mundo es posible dirigir las acciones hacia la realización del derecho. La vida ética ha llenado de contenido las prescripciones del derecho, y los sujetos que pertenecen a ese mundo tienen «certeza de su libertad» (Hegel, 1968: 155). ${ }^{139}$ La voluntad del delincuente, sin embargo, dirige su conducta a la producción de la «antítesis del derecho en sí» (Hegel, 1968: 101)..$^{140}$ Por esto, su voluntad maliciosa no es más que una mera apariencia per se nula, mientras que lo verdadero sigue siendo el derecho en sí: El castigo es la reafirmación del derecho de un mundo liberal.

\section{Similitudes entre las teorías penales de Kant y Hegel, y el derecho penal de hoy}

Actualmente, la libertad es un derecho fundamental tanto de la víctima como del delincuente y con la pena se envía un mensaje de reproche merecido por la actuación criminal. Sin embargo, atendiendo a los recientes desarrollos de la ciencia penal, podría decirse que ya en Kant y Hegel el castigo era considerado como una respuesta que busca anular el significado del discurso equivocado de un ser racional y libre y que, a pesar de ello, decidió negar una norma penal cuestionando bien sea el valor de la justicia o la vigencia del derecho abstracto. En Kant, la ley penal era un imperativo categórico que se imponía a un ser formalmente libre. Por el contrario, en Hegel la pena es el restablecimiento del derecho en un mundo en el que es posible la realización de la idea de la libertad. Así, hemos demostrado que - desde estas dos posturas del idealismo alemán - la libertad y el merecimiento de la pena son ejes centrales de la necesidad de hacer responsable al delincuente.

Por otro lado, en este ensayo se ha explicado que el principio de culpabilidad y el concepto de libertad de acción se han reinterpretado. Actualmente, podemos concluir que en nuestro orden social se imponen castigos a los ciudadanos capaces de obedecer los legítimos mandatos del derecho penal, pero los infringen. De esta

estudio de la pena se suele ignorar que hay otro sujeto al que también se encierra, aunque no sea para castigarlo, y el lugar en el que esto se lleva a acabo se le ha dado el nombre de «asilo» o «institución psiquiátrica». Hegel, basado en la contraposición abstracto-material, considera que el loco no ha perdido la razón en un sentido abstracto, sino que solo se encuentra perturbado espiritualmente y, por lo tanto, su tratamiento debe suponerlo como un ser racional. Esta es la opinión de Foucault (1967: 212-213), Hegel (2005: 461). Véase en $\$ 408$. Por el contrario, como el loco no puede actuar conforme a su pensamiento y voluntad, su responsabilidad es limitada (Hegel, 1968: 123). Véase en $\$$ 120. Cabe preguntarse si también el agente que puede actuar conforme a su pensamiento y voluntad pero que vive en un mundo hostil en el que se presupone la libertad, pero en el que no puede realizarse la idea de la libertad, debiera ser tenido por un sujeto libre a la hora de imponer la pena. La pregunta no está resuelta en términos de oposición delincuente-loco en la Filosofía del derecho, pero - como se desprende de la cita- se responde en términos de validez del derecho.

139. Véase en $\$ 153$.

140. Véase en $\$ 82$. 
definición surgen dos elementos de especial análisis: ¿En qué consiste la capacidad de los ciudadanos de infringir las normas y por qué los mandatos del derecho penal son legítimos?

Como hemos visto, para el normativismo al derecho no le importa si los ciudadanos son naturalística o psicológicamente libres. Por el contrario, para saber si a una persona se le puede imponer una pena o un tratamiento, ha de analizarse según las reglas del derecho penal si el sujeto es normal o no. En el primer caso se le castiga y en el segundo no. Asimismo, para determinar la responsabilidad de las personas imputables ha de saberse si las circunstancias en las que se desarrolló la conducta fueron normales o no según las reglas del derecho penal. En el primer caso hay pena y en el segundo puede haber una exoneración o una disminución del quantum del castigo. De esto se desprende que las reglas del derecho penal sean lo que establece qué es lo normal, sea que este adjetivo califique al ciudadano o a las circunstancias en las que actúa.

Por esto, las reglas del derecho penal deben ser legítimas. De lo contrario, ¿por qué tendrían vigencia general para los ciudadanos del orden social y cómo podrían servir de fundamento para determinar la responsabilidad del delincuente? La legitimidad de las normas - para Günther Jakobs - se desprende de que sean el producto de lo que el orden social haya dispuesto para establecerlas. Las normas que no sean establecidas por este mecanismo no son legítimas y, por lo tanto, no pueden utilizarse por el juez para establecer la responsabilidad de los ciudadanos. Los miembros del orden social no tienen la libertad de escoger si quieren pertenecer a él o no, hacen parte de él irremediablemente. Por el contrario, las personas tienen la libertad de participar en la formación de las normas jurídicas. Esto, porque el fundamento del orden social es la democracia. Lo anterior implica - para Klaus Günther-que los mandatos del derecho penal son legítimos en la medida en que sean el producto de los mecanismos participativos y deliberativos que el orden social debe garantizar como presupuestos. Es decir, los miembros de una democracia deben estar en la facultad de colegislar las normas que los gobiernan, pero una vez las normas de responsabilidad han sido producidas, entonces deben ser respetadas por los ciudadanos. Esto aplica para las reglas del derecho penal. Si los ciudadanos las infringen, serán sometidos a un proceso penal público en donde se razonará sobre si pueden ser considerados como imputables y merecedores de un castigo. Durante el proceso penal, los ciudadanos no tienen el derecho a expresar legítimamente su descontento con la norma. Allí serán tratados como sujetos responsables.

Al final, se dictará la sentencia y — si la persona era normal y actuó en circunstancias normales - se impondrá un tratamiento duro porque así se ha especificado democráticamente. La sentencia es un acto comunicativo dirigido al delincuente, a la víctima y a la sociedad, ya que - al ser seres morales- son capaces de entender el reproche que se le hace al delincuente. El mensaje dice que el criminal fue culpa- 
ble en el sentido de las reglas del derecho penal por no haber actuado conforme los mandatos democráticos que las definen. Asimismo, comunica que el delito no es el medio adecuado para expresar el descontento con la configuración del orden social. Es decir, se le expresa al delincuente que es culpable de no haber hecho uso de algún mecanismo democrático para trasmitir su descontento con la norma jurídica que finalmente ha infringido.

Estas ideas ya rondaban en el idealismo alemán. Para Kant, por ejemplo, el delito es una negación producto de la voluntad libre del mandato que la razón pura jurídicolegisladora había establecido. Es decir, las normas que deben ser respetadas por los sujetos de la república y que, por su parte, ya han sido definidas por la razón pura previamente a la celebración del contrato social, se dirigen especialmente al ser racional (homo noumenon). Por otro lado, la legitimidad de la república se deduce del mandato de la razón, de darle paso al nacimiento de un derecho público que garantice las prácticas y los principios del derecho privado regido por las leyes a priori de la libertad. Por consiguiente, por medio de la coacción se hacen respetar las esferas individuales de sus miembros. En cambio, para Hegel las intenciones de la voluntad subjetiva solo tienen sentido en cuanto la vida ética les da contenido a las prescripciones del derecho. Es decir, para él, la vida ética le permite al individuo conocer las prescripciones o los mandatos y, por consiguiente, el agente se puede motivar espontáneamente a cumplirlos. En su sistema, la conducta delictiva del delincuente es una voluntad maliciosa que niega la validez del derecho en sí, pero que no es más que una apariencia. La pena, a su vez, anula esa apariencia y, como tal, el restablecimiento del derecho en cuanto derecho. Como la sociedad actual tiene la configuración de una democracia, las normas - siguiendo a Klaus Günther- son válidas en la medida en que sean el producto de la deliberación de ciudadanos capaces de dar y comprender razones. Esto, en la medida en que los ciudadanos gozan de derechos participativos que pueden ser materializados a través de los procedimientos que para ello se han establecido y garantizado. Así, las reglas del derecho penal definen qué es lo normal, pero solo son legítimas en la medida en que sean el resultado de lo que dispuso el orden social para su formación: el proceso democrático.

La diferencia fundamental de la perspectiva democrática de Günther con las visiones de Kant y Hegel consiste en que - para él- los ciudadanos son tratados como seres libres tanto en el proceso penal como en el deliberativo, es decir, son responsables de respetar y de crear las normas. Con el imperativo categórico kantiano y con el historicismo hegeliano, no es posible concebir al ciudadano como verdaderamente responsable de participar en la formación de las normas. Esto se debe a que, en el sistema kantiano, es homo noumenon, mas no phaenomenon (el sujeto que se castiga penalmente), quien participa en la constitución del contrato social, ya que «el legislador es santo». Por otro lado, la valoración de la conducta del sujeto moral hegeliano se define por el sentido de las dimensiones de la vida ética práctica, que les da contenido a 
los mandatos de respeto del derecho abstracto y a los deberes mínimos de solidaridad y asistencia a partir de las instituciones sociales propias de la sociedad burguesa en la que el sujeto nace. Es decir, en estas dos perspectivas, el individuo no es considerado como un sujeto que tiene la posibilidad de participar en el proceso deliberativo de formación de las normas jurídicas que le gobiernan. El cambio de perspectiva que se acaba de explicar es la esencia del planteamiento de la ética discursiva.

Sin embargo, esta diferencia tiene la forma de un presupuesto. Para que las normas sean legítimas, la sociedad solo debe garantizar la existencia de procedimientos para materializar su ejercicio. Por lo tanto, en nada importa que el delincuente haya participado en la formación de las normas porque con que haya tenido el derecho efectivo de hacerlo es suficiente. Pongámoslo en palabras más ilustrativas: Al delincuente se le condena porque se presupone que pudo especificar cómo colgar su propia soga, pero lo trascendental es que es responsable tanto del pecar como del legislar.

Se puede concluir que antes la ley penal era un imperativo categórico, después el castigo fue concebido como la restitución del derecho como derecho y ahora el proceso penal es la forma de especificar el mensaje legítimo de la Democracia. En todo caso, solo se imponen penas a las personas imputables, es decir, a las personas responsables de dirigir sus acciones conforme a las normas o a los ciudadanos competentes de administrar su ámbito de organización. En la actualidad, las normas son legítimas en la medida en que su formación sea el resultado de los procedimientos que la comunidad democrática ha establecido, sin embargo, y esta es la cuestión de fondo, ¿en qué han cambiado las reglas penales?

\section{Acerca del origen de la idea «el pecador es libre»}

\section{La postura platónico-aristotélica}

En las actuales democracias seculares se sostiene un concepto normativo de libertad que, en principio, es ajeno al libre albedrío. A continuación, vamos a presentar cómo se explicaba en la filosofía moral de la antigüedad el dualismo mente-cuerpo que tradicionalmente se había utilizado para poder hablar del dolo, la culpabilidad, la libertad, el conocimiento, etcétera. ${ }^{141}$ Según esta visión del ser humano, la mente escoge los medios para realizar un acto con el cuerpo, es decir, el estado mental causa actos externos (Agretelis, 1965: 19). De allí que pueda decirse que alguien es autor de un hecho en virtud de su estado mental (Agretelis, 1965: 20). El origen de esto puede ser rastreado en la filosofía platónico-aristotélica que se explica a continuación. ${ }^{142}$

141. Al respecto, véase Levitt (1922-1923) y Agretelis (1965).

142. Sobre el mens rea, véase Agretelis (1965: 20-21). 
Según Platón, la mayoría de las cosas tienen una función para la que son el mejor o el único instrumento, y lo que permite prestar dicha función se llama virtud (arete) (Platón, 1992: 42-44). Por ejemplo, el cuchillo (instrumento) es al filo (virtud) que corta (función) (Agretelis, 1965: 23) lo que la lámpara al bombillo que brilla. Así, el alma del ser humano tiene la función de vivir y la virtud de la justicia (Platón, 1992: 22-23). La naturaleza del alma tiende a que se persiga lo que le da placer al hombre (apetitos irracionales, alma concupiscible), sin embargo, la reflexión apacigua el deseo y hace que se opte por la prudencia (por lo moderado, alma racional) (Agretelis, 1965: 23-24). Quien opta por los apetitos irracionales y se arrepiente hace uso de su alma irascible, que es la fuente de pasiones nobles y se encuentra subordinada - junto al alma concupiscible - a la racional (Agretelis, 1965: 24). Quien encuentra el equilibrio entre las tres partes del alma es un hombre templado; quien deshonre este buen habito de la mente, obrará injustamente contra sí mismo y no podrá ser un hombre feliz (Agretelis, 1965: 24).

Por lo tanto, la justicia consiste en un comportamiento interno de armonía del alma. Es en el alma - no en el cuerpo- donde se encuentra la virtud, ya que el alma es eterna al ipertenecer al mundo de las ideas! (Agretelis, 1965: 25) Por lo tanto, es lo que debe juzgarse para saber si un hombre debe ir o no a prisión: Se castiga en virtud de su estado del alma (Platón, 2016). ${ }^{143}$ Sin embargo, de acuerdo con Platón no existen injusticias voluntarias porque la función de la vida justa es la felicidad, lo que implica que todas las acciones voluntarias se dirigen hacia ella (Agretelis, 1965: 23-26). Por esto, en su doctrina debe entenderse por «injusticia» el gobierno del alma concupiscible sobre la racional, y por «castigo» la forma de curación del alma configurada de forma desequilibrada (Agretelis, 1965; Platón, 2016)..$^{144}$ El legislador debe hacer leyes nobles en este sentido: Debe mandar la aplicación de un tratamiento a las almas curables para que se alivien y, por el contrario, debe ordenar la imposición de la pena de muerte a las almas incurables como forma de advertencia a los demás y para inocuizar al pecador, que en nuestros días podría ser un loco (Agretelis, 1965: 27). Sin embargo, para Platón la voluntad no era un requisito para la imposición de la pena: «La virtud no tiene dueño; cada uno la poseerá, en mayor o menor grado, según la honra o el menosprecio que le prodigue. La responsabilidad será toda de quien elija, porque la divinidad es inocente».145

La filosofía moral de Aristóteles es muy similar. La felicidad es el bien final en sí mismo, el fin que no es instrumento de ningún otro (Agretelis, 1965: 28-29; Aristóteles, 2005: 58). Para el hombre, el bien final es una actividad virtuosa (¡otra vez!) del

143. Véase en $\$ 524 \mathrm{a}, 524 \mathrm{~b}$.

144. Véase en $\$ 472 e$.

145. Vale la pena recalcar la semejanza con el pasaje que ya estudiamos en este ensayo en el que Kant dice que el legislador es santo (Platón, 1992: 510). 
alma que se divide en tres partes: la vegetativa, la sensitiva y la racional (Agretelis, 1965: 72-73). Cada una de las partes del alma tiene una virtud y entre ellas nos interesa la moral. Ella es un estado mental que le permite al hombre funcionar bien al encontrar el punto medio de sus pasiones y de sus acciones (Agretelis, 1965: 29-30). Por otro lado, con respecto a los actos justos - que estudiaremos más adelante-dice que constan de conocimiento, elección y un estado del carácter particular o estado mental» (Agretelis, 1965: 30; Aristóteles, 2005: 81).

Con la llegada del cristianismo, la filosofía moral de la antigua Grecia fue retomada. Para San Agustín (1981: 288, 308) —adaptando la filosofía de Platón-, el pecado original hizo que los hombres perdieran todo lo sagrado de sus almas. ${ }^{146}$ Dios - con el bautizo- dota a los elegidos de un nuevo espíritu que, aunque no les libera de pecado, les dota de la gracia necesaria para superar la pecaminosidad. ${ }^{147}$ El alma siente miedo por el mal - aunque en realidad el mal no existe- y deseo por la felicidad y la bendición. ${ }^{148}$ La voluntad, producto del deseo, no es libre en sí misma, sino que requiere que su único motivo sea el anhelo por el bien (cupiditas boni) para poder llegar a ser libre y que sus obras sean buenas. ${ }^{149}$ Es decir, «solo la buena voluntad es voluntad libre» (Levitt, 1922-1923: 130). Cuando está ausente el anhelo por el bien, cuando la voluntad se inclina por el mal, se producen las obras malvadas o pecaminosas. Entre menor sea la inclinación por el bien, más execrables serán las obras y viceversa. Por lo tanto, los motivos de las acciones definen si son buenas o malas: «Actus non facit

146. "Así que no solo cayó el hombre con aquella si ilícita y vana presunción o le arrojaron y condenaron con justísismo decreto a la rudeza y flaqueza de niños, sino que la naturaleza humana quedó corrompida y mudada, de manera que padeciese en sus miembros la desobediencia y repugnancia de la concupiscencia, y quedase sujeta a la necesidad de morir, y así engendrase lo que vino a ser por su culpa y por la pena y castigo que en él hicieron, esto es, hijos sujetos al pecado y a la muerte» (San Agustín, 1981: 289). Sobre el punto, véase Levitt (1922-1923: 130).

147. Sobre el bautismo: «Y cuando los niños se libran de esta sujeción del pecado por la gracia de Jesucristo, nuestro mediador y redentor, solo pueden padecer la muerte que aparta y divide al alma del cuerpo, pero no pasan a aquella segunda de las penas eternas, porque están ya libres de la obligación del pecado» (San Agustín, 1981: 289).

148. «Dios crió al hombre recto, como verdadero autor de las naturalezas, y no de los vicios; pero como este se depravó en su propia voluntad, y por ello fue justamente condenado, engendró asimismo hijos malvados y condenados» (San Agustín, 1981: 295-296).

149. «Y así del mal uso del libre albedrío nació el progreso y fomento de esta calamidad [el pecado original], la cual, desde su origen y principio depravado, como de una raíz corrompida, trae al linaje humano con la trabazón de las miserias hasta el abismo de la muerte segunda, que no tiene fin, a excepción de los que se escapan y libertan por beneficio de la divina gracia» (San Agustín, 1981: 296). Por otro lado, "para conseguir la eterna felicidad no es necesario huir de cualesquiera cuerpos, sino de los corruptibles, molestos, graves y mortales, no cuales los crió la voluntad de Dios o los primeros hombres, sino cuales les obligó a ser la pena del pecado» (San Agustín, 1981: 298). 
reum, nisi mens sit rea». ${ }^{150}$ Como para San Agustín la Iglesia podía perdonar todos los pecados y era el camino del señor, la religión fecundó a la moral.

Acá ya se puede identificar quién es un pecador: La religión hace penitentes a los pecadores porque considera que fueron libres de tomar la decisión de obedecer los mandatos de Dios, pero no se motivaron por hacerlo. La tradición judeocristiana bebió de los aportes platónicos y aristotélicos que le permitieron dar una buena explicación de cómo actúa quien peca, sin embargo, la idea ya se encontraba en el corazón de la religión.

Similitudes entre algunas de las instituciones del derecho penal actuales y la moral platónico-aristotélica cristiana

De antemano, advertimos que en este espacio nos es imposible resolver la cuestión de forma completa. Sería necesaria la realización de un trabajo autónomo en el que se explicara, según los diferentes esquemas del delito, la forma en que las instituciones que implican alguna forma de libertad han sido reinterpretadas para obtener una obra «pura» en el sentido dogmático de la palabra. Esperamos tener la posibilidad de contar con el espacio indicado para analizar las continuidades y discontinuidades que han fluctuado dentro de dichas instituciones desde la antigüedad en un futuro próximo, pero por ahora bástenos con relacionar las ideas más importantes que hemos encontrado en textos de diferentes épocas del cristianismo -o que hayan tenido influencia en él- con la finalidad argumentativa de resolver la pregunta que hemos enunciado.

Comencemos con Aristóteles. En la Ética a Nicómaco (Aristóteles, 2005: 81) se puede encontrar la siguiente cita:

Aquello que se realiza conforme a las virtudes no se realiza con justicia o con templanza porque estas mismas acciones sean de una determinada manera, sino porque, además, las realiza el agente estando de una determinada manera: En primer lugar, si actúa con conocimiento; después, si lo hace por elección y si las elige por ellas mismas; $y$, en tercer lugar, si también las realiza manteniéndose firme e inconmovible.

Así - como sostiene Demetrios Agretelis (1965: 30-31) -, las acciones justas en la filosofía aristotélica no son el producto de una compulsión externa, como la acción de otro hombre, ni son causadas por la naturaleza, es decir, la acción justa es voluntaria. Por otro lado, la ignorancia, en contraposición con el conocimiento que debe tener quien actúa de forma justa, puede versar sobre la acción o los objetos de la ac-

150. Esta sentencia ha inspirado múltiples formulaciones del mens rea en el derecho anglosajón. De hecho, en esta tradición se ha aceptado que el origen del término proviene de San Agustín (Levitt, 19221923: 131; Agretelis, 1965: 22). 
ción, es decir, «sobre lo que alguien está haciendo, el instrumento que está utilizando y la forma en la que lo hace, por ejemplo, suave o violentamente» (Agretelis, 1965: 31). Asimismo, la elección (o voluntad) se refiere a la selección deliberada por parte del sujeto de los medios para lograr algún fin (Agretelis, 1965: 31). A contrario sensu, las acciones provocadas por la fuerza impuesta por otro hombre o que sean causadas por la naturaleza no pueden ser consideradas como acciones injustas. Por otro lado, las que sean causadas por el desconocimiento que recaiga sobre la acción o sobre los objetos con los que la realiza tampoco son injustas. Finalmente, sobre el estado del carácter hay que decir: Si el sujeto actúa con conocimiento, pero sin deliberación (verbigracia, con rabia), su acto es injusto, pero la persona no; y si actúa con elección, tanto su acto como su persona son injustos (Agretelis, 1965:32). Acá se puede identificar - a grandes rasgos - lo que actualmente se denomina estado de necesidad, error de tipo y atenuación de la pena por estado pasional o por ira provocada injustamente.

Una de las razones por las cuales la tradición helénica no fue difícil de asimilar por el cristianismo es porque, en los libros de la religión judeocristiana, ya se encuentran diversos conceptos relacionados con la voluntad libre y el delito. En las leyes hebreas, la distinción entre actos intencionales y no intencionales se puede encontrar en los libros sagrados, en los que la culpa determinaba el castigo (Levitt, 1922-1923: 127). Por ejemplo, en el Éxodo (21: 12-17, 22: 3b, 21: 28-29), en el Libro de los Números (35: 15-24) y en el Deuteronomio (5:17) se decía que quienes mataran sin intención podían asilarse en las ciudades de refugio. En cambio, quien lo hiciera con intención debía morir (Levítico 24: 17, 24: 21; Génesis 9: 5-6) (Levitt, 1922-1923: 123-124). Esta institución -otra vez- no es la misma que actualmente nos permite distinguir con alto grado técnico-jurídico entre los delitos dolosos y los imprudentes, pero nos permite confirmar que para las leyes hebreas un delito cometido voluntariamente era distinto a uno cometido sin intención. Por otro lado, en el caso del adulterio, la pareja que había actuado injustamente debía morir (Deuteronomio 5: 18 y 22: 22; Libro de los Números 5: 21-31), pero si por el contrario se configuraba violación, al violador se le debía dar muerte. Esta diferenciación es muy relevante si se tiene en cuenta que por la comisión de delitos como el hurto se caía en esclavitud (Levitt, 1922-1923: 124). Asimismo, nos permite identificar que la motivación de la acción de la mujer, quien en realidad no cometía ningún delito, ya era tenida en cuenta para establecer el castigo del violador (Levitt, 1922-1923: 126-127). La pena también se modulaba en el caso del perjurio y del desacato judicial según se cometiera con o sin intención (Deuteronomio, 19: 16-21,17:12; Libro de los Números, 15: 30-31), lo que podría relacionarse con el actual concepto de error.

El concepto de voluntad no solo era importante para la tradición judeocristiana primitiva en relación con los delitos, sino que, como es natural, también en relación con la expiación de los pecados (Levitt, 1922-1923: 127). Si se ignoraba o se infringía por accidente un mandato de Dios, se tenía el deber - en cuanto el ofensor tuviese 
conocimiento de su existencia - de realizar la expiación (Levítico, 5: 4). En cambio, si se hacía con intención, debía ser destruido (Libro de los Números, 15: 30-31). En estos versículos se puede encontrar la idea que es eje central de lo que actualmente se denomina error de prohibición.

Por otro lado, ya en la Biblia se puede encontrar el concepto de responsabilidad personal. En un principio, la expiación de la culpa debía realizarse por parte de la tribu (Jeremías, 31: 29-30). Posteriormente, como se puede desprender de lo dicho por Jesús en el Sermón de la Montaña, la responsabilidad era de cada hombre que con codicia deseara a otra mujer (Mateo 5: 27-28) (Levitt, 1922-1923: 128).

Por todo esto, fue inminente el desenlace: En el ocaso del siglo VI, el papa Gregorio Magno formuló finalmente la doctrina que indica que el mal puede ser compensado con acciones buenas, es decir, que las penitencias pueden absolver a los pecadores (Levitt, 1922-1923: 131-132). Los libros penitenciarios - que tuvieron acogida en todo el mundo cristiano e influenciaron algunas legislaciones y al derecho canónico- ${ }^{151}$ aluden al pecar con el corazón y a la determinación del castigo según el grado de la culpa. ${ }^{152}$ No debemos sorprendernos de todo lo anterior. Según Klaus Günther (2003: 265), se podría llegar a decir que la diferencia entre la culpabilidad y la antijuridicidad -dos de los tres conceptos centrales de la teoría del delito- se encuentra en que, en esta, la acción es «buena o mala»y, en aquella, «voluntaria o no». Como hemos visto, no es en stricto sensu la opinión del autor - para quien la libertad de acción solo tiene una función comunicativa e intersubjetiva-, pero él mismo dice que los conceptos de enfermedad mental, error y estado de necesidad son ampliamente aceptados por la dogmática penal sin importar que impliquen alguna forma de libertad o deban tenerse en cuenta las motivaciones internas del sujeto (Günther, 2003: 269-271). ${ }^{153}$ Por este motivo, como hemos explicado, Dios y la libertad han hecho necesario dejarle un sitio a la fe.

\section{Paseo nocturno: Un ensayo para todos y para nadie}

Después de todo lo dicho, se puede entender la relevancia de la filosofía moral en relación con el origen del derecho penal. Sin embargo, Nietzsche ya advertía que el poder de la Iglesia se encontraba en decadencia para su época y esto no deja de ser cierto en la actualidad: Los Estados seculares se definen porque no pueden fundamentarse a sí mismos ni a sus normas con base en principios o razones teológicas, pero la pregunta que resulta como consecuencia de todas nuestras meditaciones es: $¿$ Realmente Dios ha muerto? Entre los renglones de este ensayo ha rondado desvelada y silenciosamente un espíritu retórico con tendencias hacia la similitud. Es que de

151. Por ejemplo, las Leges Henrici Primi (Levitt, 1922-1932: 132-134).

152. Por ejemplo, los penitenciarios irlandeses de Vinnian y Theodori (Levitt, 1922-1923: 132-134).

153. En este texto se explica el argumento con el exceso de legitima defensa y el caso de necesidad. 
cerca una piedra puede parecer una enorme montaña y «entre las cosas más semejantes es precisamente donde la ilusión miente del modo más hermoso; el abismo más pequeño es el más difícil de salvar» (Nietzsche, 2011a: 353).

\section{Un conocimiento silenciado}

Hemos tomado trágicas y cómicas metáforas, pero es hora de explicar con franqueza en qué consiste nuestra intención. Para esto, debemos dar cuenta de algunas ideas que se encuentran en la Genealogía de la moral de Friedrich Nietzsche. En este libro, el autor se propone estudiar el valor de los valores morales, hazaña hasta ese entonces nunca vista porque siempre se había considerado que este tipo de valores eran ciertos e indiscutibles (Nietzsche, 2011b: 33). Por este motivo, analizó en qué medida lo «bueno» es realmente mejor que lo «malo» en un sentido de utilidad o beneficio "para el ser humano como tal (incluido el futuro del ser humano)».154 Así, comenzó una genealogía gris ${ }^{155}$ sobre la moral y advirtió que la verdad podía llegar a ser repugnante o no-cristiana (Nietzsche, 2011b: 40).

Según el autor, existe un conocimiento esencial en el estudio de la moral que ha sido silenciado por la democratización del mundo moderno: El origen primitivo de las palabras «bueno»y «malo» proviene de una contraposición que hace el ser humano noble frente al vulgar para designar que tiene una «preeminencia anímica» $o$ una fortaleza de carácter. ${ }^{156}$ Por otro lado, las palabras «puro»e «impuro» vienen de

154. En la actualidad, la afirmación «los valores son ciertos e indiscutibles» fundamentada desde una perspectiva metafísica o material (en el sentido opuesto a procedimental) tiene cada vez menos seguidores. Véase en Günther 1991. Sin embargo, le hacemos unas preguntas personales al lector: ¿Qué piensa sobre la misericordia con los pobres? ¿Qué piensa sobre la igualdad laboral? ¿Qué piensa sobre la honestidad en el sector público? ¿Qué piensa sobre el pago oportuno de sus créditos? Según sus respuestas puede entreverse si se trata de un delincuente en potencia (al ser normal y actuar anormalmente en circunstancias normales), un loco irremediable (al no ser normal y no actuar normalmente) o un inocente (al actuar normalmente). Por fortuna, solo por sus acciones se decidirá si se le corona, encierra o absuelve. De hecho, de eso se trata todo el asunto que discutimos en este ensayo: «Es decir, del mismo modo que el pueblo separa el rayo de su resplandor y concibe el segundo como un hacer, como la acción de un sujeto que se llama rayo, así la moral del pueblo separa también la fortaleza de las exteriorizaciones de la misma, como si detrás del fuerte hubiera un sustrato indiferente, que fuera dueño de exteriorizar y, también, de no exteriorizar. Pero tal sustrato no existe; no hay ningún «ser» detrás del hacer, del actuar, del devenir; «el agente» ha sido ficticiamente añadido al hacer, el hacer es todo» (Nietzsche, 2011b: 67). Como en este texto solo hacemos referencia al hacer delictivo, la siguiente cita es sumamente aclarativa de nuestras preguntas personales: «Es un privilegio absoluto de la locura el reinar sobre todo aquello que hay de malo en el hombre. Y por lo tanto reina también sobre todo el bien que puede hacer: sobre la ambición, que hace a los políticos hábiles; sobre la avaricia que aumenta las riquezas; sobre la indiscreta curiosidad que anima a filósofos y sabios» (Foucault, 1967: 44).

155. Con gris el autor se refiere a que se basa en documentos (Nietzsche, 2011b: 34).

156. También existían nombres que les distinguían por la superioridad de poder, pero la distinción por 
la distinción que hacían los sacerdotes frente a los nobles por su alimentación, su asco a ciertas sustancias y su dedicación a las ideas (Nietzsche, 2011b: 49). En esta última distinción, Nietzsche (2011b: 50) advierte que hay algo «no sano» en los hábitos especialmente sedentarios de la casta sacerdotal que los lleva a la búsqueda de la Nada o del Todo (del Buda o de Dios), en la que «se vuelve más peligroso todo [...] la soberbia, la venganza, la sagacidad, el desenfreno, el amor, la ambición de dominio, la virtud, la enfermedad». Por este motivo, los juicios de valor de los sacerdotes son contrarios a los de los nobles-caballeros, para los cuales la salud y la fuerza son lo que les permite llevar a cabo sus aventuras (Nietzsche, 2011b: 51). Como los sacerdotes son impotentes, en ellos crece el odio, se vuelven los enemigos más peligrosos y se convierten en los únicos capaces de vengarse con una transvaloración (Nietzsche, 2011b: 51-52).

Así, dirigida por los sacerdotes, surge la rebelión moral de los esclavos, que tiene como producto un orden en el que se califica como «buenos» a los pobres, a los enfermos y a los miserables; en cambio, a los nobles les da el nombre de malvados, violentos, crueles y ateos (Nietzsche, 2011b: 51-52). Después de esta revolución quedó vigente el juicio de valor judeocristiano que ha triunfado silenciosamente desde la llegada del Cristo (Nietzsche, 2011b: 53). Esta moral es de carácter reactivo porque surge de una venganza imaginaria que le dice «no» a la nobleza, es decir, siempre está en comparación con ella (Nietzsche, 2011b: 56). En cambio, la moral noble se caracteriza por ser activa y espontánea (son guerreros), las comparaciones con los infelices tienen un "pálido contraste» (Nietzsche, 2011b: 56). El ser humano noble es recto y honesto consigo mismo, actúa con franqueza, es ingenuo y se olvida fácilmente de sus contratiempos (Nietzsche, 2011b: 58-59). En cambio, para el hombre del resentimiento, la seguridad y las triquiñuelas son su alivio y «entiende de callar, de no olvidar, de aguardar, de empequeñecerse y de humillarse transitoriamente» (Nietzsche, 2011b: 58). En fin, son dos clases de moral —-dos arquetipos de persona- muy distintos.

Cuando Nietzsche (2011b: 55) se encuentra explicando esto hace una pausa frente a un epílogo demócrata que le pregunta:

¿No debiera [la Iglesia], al menos, refinarse un poco? [...] Hoy, más que seducir, aleja. ¿Quién de nosotros sería librepensador si no existiera la Iglesia? La Iglesia es la que nos repugna, no su veneno [...] Prescindiendo de la Iglesia, también nosotros amamos el veneno.

Pues bien, lo que quiere decir Nietzsche con que es necesario callar (o rumiar) es que aún no había llegado a una opinión sobre lo que sucedería con los valores judeocristianos con la llegada de la Democracia. ${ }^{157}$ Este silencio ha sido la inspiración de

su carácter es la que le importa a Nietzsche (2011b: 45).

157. «QQué extraños interlocutores he encontrado! / Quiero rumiar durante largo tiempo sus palabras, 
este ensayo y, por este motivo, vamos a sumergirnos en la oscuridad del origen moral de la pena y de la culpa.

\section{El vencedor de Dios y de la Nada}

Como acabamos de ver, la capacidad de olvido es una de las características más importantes del arquetipo del ser humano noble. Sin embargo, para Nietzsche hay una fuerza activa de capacidad de olvido que actúa sobre todos los seres humanos para que haya un presente, para que exista la posibilidad de ser feliz y de tener esperanza, es decir, el ser humano es una criatura olvidadiza por naturaleza. Por esta razón, surge el gran problema de todas las organizaciones humanas: ¿Cómo hacer para que el ser humano no olvide sus promesas y pueda disponer del futuro? (Nietzsche, 2011b: 85). Finalmente, la solución que se le ha dado a esta pregunta es que se debe convertir a esta criatura salvaje en un animal regular o calculable para poderle hacer «responder de sí como futuro" (Nietzsche, 2011b: 85). Para esto se le da poder sobre sí y sobre su destino, se le dota de «una auténtica conciencia de poder y libertad, un sentimiento de plenitud del ser humano en cuanto tal» y se le da el nombre de individuo soberano (Nietzsche, 2011b: 86). Esta solución es ya tardía y elaborada, para poderle dar una conciencia de culpa al ser humano es necesario haber hecho con anticipación un ejercicio de mnemotecnia para que no olvide algunas ideas. La herramienta más usual y útil para que el hombre recuerde lo que no-quiere ha sido la aplicación del dolor (Nietzsche, 2011b: 88-89). Y «icon ayuda de esa especie de memoria se acabó por llegar a la «razón»!» (Nietzsche, 2011b: 88-89).

El sufrimiento de la pena está relacionado desde sus orígenes con la asimilación sangrienta del sentimiento de culpa (Schuld) y el de deudas (Schulden) (Nietzsche, 2011b: 94). Este tránsito no fue tan complicado porque, de hecho, en Roma solo hasta el 326 a.C. - con la ley Poetelia Papiria de nexis - los acreedores podían dar muerte a los deudores que habían dado su cuerpo como garantía. ${ }^{158}$ En sus orígenes, la pena se impuso en medio de una "auténtica fiesta» - a la que asistían espectadores - en virtud del cólera que produce la comisión del delito (Nietzsche; 2011b: 92). Por este motivo, Nietzsche recalca que, en su nacimiento, la «culpa», la "conciencia» y la «santidad del deber» estuvieron ligados con la crueldad y con la festividad primi-

\footnotetext{
como si fueran buenos granos; ¡mis dientes deberán desmenuzarlas y molerlas hasta que fluyan a mi alma como leche!» (Nietzsche, 2011a: 416). Asimismo: «Desde luego, para practicar de ese modo la lectura como arte se necesita ante todo una cosa que es precisamente hoy en día la más olvidada - y por eso ha de pasar largo tiempo hasta que mis escritos resulten «legibles»- una cosa para la cual se ha de ser casi vaca y, en todo caso, no «hombre moderno»: el rumiar...» (Nietzsche, 2011b: 36).

158. «Aquel año se le proporcionó a la plebe romana, en cierto modo, un nuevo estreno de la libertad, porque dejó de haber esclavitud por deudas, cambio jurídico debido a la lujuria a la vez que a la notable crueldad de un usurero» (Tito Livio, 1990: 8.28).
} 
tiva. ${ }^{159}$ Posteriormente, el hombre aprendió a sentirse avergonzado frente a este tipo de celebraciones - con marcado componente instintivo-y, por lo tanto, la crueldad sufrió un fenómeno de ««espiritualización» y «divinización»», se ha ido volviendo más delicada y sublime (Nietzsche, 2011b: 96-99). Así, por analogía con el derecho de obligaciones, se dice que todo delito tiene una contraprestación: la pena. En la medida en que la comunidad es más fuerte, el equivalente del delito puede ser menor porque el castigo se impone como una respuesta a una infracción frente a la totalidad (Nietzsche; 2011b: 103). Por lo tanto, la cantidad de sufrimiento que se le impone al delincuente - según Nietzsche- se «suaviza» en la medida en que la infracción pone en peligro en menor medida a la comunidad -0 , en otras palabras, porque produce menos cólera a la totalidad del acreedor (Nietzsche, 2011b: 103-106).

No se debe confundir el fin con el origen de la pena: La pena castiga, pero no se inventó para ello (Nietzsche, 2011b: 112). La pena ha tenido la finalidad que la voluntad de poder le ha dado en los diferentes momentos de la historia. Para Nietzsche (2011b: 115-116), en la actualidad no se puede sostener un único sentido de la pena ni una sola forma de castigo, ni se podría reconocer un camino lineal de progreso de estos, sino una adaptación interpretativa propiciada por el hecho de que un poder más fuerte domina a uno más débil (Nietzsche, 2011b: 113). Por este motivo, el autor le da el nombre de «elemento fluido» a la finalidad de la pena.

En cambio, Nietzsche (2011b: 117) estudia con especial atención la expiación de la mala conciencia del delincuente. Y es que la mala conciencia no se originó en los tribunales, donde el delincuente es autor de un daño. Por supuesto que tampoco tiene su origen en el fuero interno de los criminales, quienes inclusive pueden ver la condena como un gaje del oficio (Nietzsche, 2011b: 119). De hecho, para Nietzsche el auténtico efecto de la pena no es expiar la culpabilidad, sino intensificar la inteligencia humana y el temor frente al castigo, lo que no siempre ocurre con los criminales. ${ }^{160}$ Por lo tanto, la mala conciencia no tiene por qué ser estudiada como un fin de la pena, pero sí está íntimamente ligada con el castigo. El origen de la mala conciencia se encuentra en el «sortilegio de la sociedad y de la paz», producto de múltiples instrumentos de la cultura, entre ellos la pena (Nietzsche, 2011b: 121-122). Antes de esta domesticación del ser humano salvaje y libre, los impulsos naturales de este animal se exteriorizaban en la caza, la reproducción y demás actividades. ${ }^{161}$ Por el contrario, con la civilización los instintos quedan «desvalorizados y «en suspenso»» (Nietzs-

159. «Ni siquiera en el viejo Kant: el imperativo categórico huele a crueldad» (Nietzsche, 2011b: 95-97). 16o. «Por fortuna, [el delincuente] también vuelve, con frecuencia, bastante tonto» (Nietzsche, 2011b: 121).

161. «La enemistad, la crueldad, el placer en la persecución, en la agresión, en el cambio, en la destrucción - todo esto vuelo contra el poseedor de tales instintos: ese es el origen de la «mala conciencia»» (Nietzsche, 2011b: 122). 
che, 2011b: 121), y se hace necesaria su interiorización. Las primeras organizaciones humanas no conocen de los términos culpa ni responsabilidad, sin embargo, con su formación -intempestiva y violenta- (Nietzsche, 2011b: 124) «un ingente quantum de libertad [el llamado instinto de la libertad] fue arrojado del mundo [...] y [...] quedó latente», se volcó al interior reprimido del animal domesticado (Nietzsche, 2011b: 125-126). La mala conciencia es el producto de este cambio de dirección de la libertad, los instintos dejaron de ir hacia afuera y se dirigieron hacia adentro. Con ella, se hace necesario el surgimiento del valor moral de lo no-egoísta, según el cual el sacrificio y la abnegación son «belleza» aunque no sean más que crueldad consigo mismo (Nietzsche, 2011b: 126-127).

Para Nietzsche (2011b: 127-128), en las organizaciones humanas primigenias existió una auténtica obligación jurídica de las generaciones actuales con las antepasadas, que se materializaba con la entrega de ofrendas y, más importante, en el cumplimiento de sus mandatos o costumbres. Esta deuda (Schuld) con los antepasados llegó a su cumbre con el cristianismo (Nietzsche, 2011b: 130-131): El «Cristo sufrió por nuestros pecados una sola vez y para siempre» (Pedro, 3 :18). La deuda entonces es originaria, eterna y, sobretodo, con Dios (Nietzsche, 2011b: 131). El acreedor del cristianismo se sacrificó por amor a su deudor, convirtiendo a la mala conciencia en el mejor instrumento de tortura (Nietzsche, 2011b: 133-134). Con esta genial forma de automartirio no-egoísta divino se manifestó el «máximum del sentimiento de culpa» (Nietzsche, 2011b: 131-133).

Es decir, el acreedor cristiano tiene una herramienta de manipulación extraordinaria para que el ser humano actúe según sus juicios de valor moral. Démosle la palabra a Nietzsche (2011b: 134) para explicar a qué nos referimos con que la libertad tiene profundas raíces en nuestra sociedad. En relación con la conciencia de culpa cristiana dice:

Es esta una especie de demencia de la voluntad en la crueldad anímica que, sencillamente, no tiene igual: la voluntad del ser humano de encontrarse culpable y reprobable a sí mismo hasta resultar imposible la expiación, su voluntad de imaginarse castigado sin que la pena pueda hacer jamás equivalente a la culpa, su voluntad de infectar y de envenenar con el problema de la pena y la culpa el fondo más profundo de las cosas, a fin de cortarse, de una vez por todas, la salida de ese laberinto de «ideas fijas» [interiores e instintivas], su voluntad de establecer un ideal -el del «Dios santo»-, para adquirir, en presencia del mismo, una tangible certeza de su absoluta indignidad.

El hilo conductor de este ensayo es la libertad y la pregunta por qué se dotó de voluntad al ser humano. Pues se le dotó de libertad porque «un mundo pensado de manera completamente determinista habría resultado adivinable para los dioses y, en consecuencia, también fastidioso al poco tiempo» (Nietzsche, 2011b: 101). Por esto, 
los filósofos morales de la Antigüedad - particularmente Platón y Aristóteles- ya habían inventado la voluntad libre. Sin embargo, en la cultura helénica era posible divinizar al animal en el ser humano y la felicidad del alma libre (Nietzsche, 2011b: 136). Para los griegos, los Dioses habían perturbado la cabeza de quienes con ¡locura! manchaban sus manos de sangre, es decir, «los dioses no asumían la pena, sino, como es más noble, la culpa» (Nietzsche, 2011b: 137). En cambio, con la valoración judeocristiana se le comienza a llamar pecado a la locura griega.

\section{Conclusión: La compasión de la democracia}

A partir de nuestro análisis, puede concluirse que actualmente el castigo tiene una faceta comunicativa con la función de enviar un mensaje que reprocha la conducta criminal. También que la deliberación es un presupuesto democrático, es decir, que los ciudadanos tienen el derecho y la posibilidad de deliberar, pero que no se requiere que su participación sea efectiva para condenarles. Por este motivo, el delincuente es castigado por ser culpable de autodeterminar sus esferas de organización expresando su descontento con las normas por un medio ilegítimo, ya que al momento de cometer su acción le fue posible actuar de otra forma. Uno de los privilegios señoriales más importantes es el de dar nombres $y{ }_{1}^{162}$ por esto, se ha cambiado el de «Dios» por «democracia», el de «deber de conciencia» por el de «normas legítimas» y el de «fundamentación metafísica» por el de «ética discursiva». No obstante, como podemos ver, "prescindiendo de la Iglesia, también nosotros amamos el veneno». La libertad y la culpa siguen siendo el eje central tanto del delito laico como del pecado religioso. A las afueras de la Iglesia a los pecados más graves les damos el nombre de «delitos», pero ¿ ha muerto Dios? Nuestra tesis es que el derecho de crédito simplemente ha sido heredado tras la «caída» de la Iglesia por la Diosa de la Democracia, quien confiesa:

Todos deben respetar las normas legítimas, porque todas provienen del proceso deliberativo y las que existen son producto de la Democracia. En consecuencia, el que se resiste a las normas legítimas se opone a los principios deliberativos de la sociedad participativa, atrayendo sobre sí el reproche moral. Los que observen estos principios no serán sometidos al proceso penal, pero sí los que se oponen por fuera del marco participativo a las normas aparentemente legisladas. Si no quieres ser reprochado, obra de acuerdo con las normas legítimas y recibirás un merecido elogio porque la autoridad es un instrumento de la Democracia que trata como seres morales a los ciudadanos. Pero teme si comunicas un mensaje prohibido, porque la autoridad no ejerce en vano su poder, sino que está al servicio de la Democracia

162. «El derecho señorial a dar nombre va tan lejos que nos deberíamos permitir comprender el origen del lenguaje mismo como la expresión del poder de quienes ejercen dominio sobre los demás». (Nietzsche, 2011b: 42). 
para exigir sus formas y someter al proceso penal al que manifiesta su descontento por medio de un procedimiento inadecuado. Por eso es necesario someterse a la Autoridad, no por temor al castigo sino por la imposibilidad de vivir fuera de esta sociedad. Y por eso también, ustedes deben pagar los impuestos: los gobernantes, en efecto, son funcionarios al servicio de la Democracia encargados de cumplir este oficio. Den a cada uno lo que le corresponde: al que se debe impuesto, impuesto; al que se debe contribución, contribución; al que se debe respeto, respeto; y honor a la ¡Democracia! ${ }^{163}$

Este es el principio innegable del derecho penal democrático, ya que antes la autoridad era la Biblia y los argumentos eran los de Platón y Aristóteles, después los de Kant y Hegel, y actualmente la autoridad es del pueblo. A partir de nuestro estudio de las teorías penales de Kant y de Hegel, demostramos que para estos autores la libertad y el merecimiento de la pena son la piedra fundamental de la necesidad de responsabilizar al delincuente. También explicamos que el principio de culpabilidad y el concepto de libertad de acción han sido reinterpretados y que con el normativismo se llegó a la conclusión de que la libertad para el derecho penal no es una realidad naturalística o psicológica, sino una regla de conducta que determina si el delincuente y las circunstancias que rodearon la comisión del delito eran normales o no. Además, dijimos que la legitimación de las normas que establecen estos criterios es una exigencia de la culpabilidad en un sentido material, o sea, que sean un producto de la deliberación de un orden democrático. Sin embargo, cuando se dice «deberíamos responsabilizarnos en las formas en que especificamos la responsabilidad», evadiendo una respuesta cualitativa, se nos entrega un dogma deliberativo y trasmundano. El sincero y mutuo entendimiento, y las razones justificadas que deben ofrecerse en medio de un procedimiento democrático garantizado se basan en la siguiente ficción: Las normas se suponen realizadas por ciudadanos que deliberan. ¡Jesús sufrió por nuestros pecados y el sentimiento de culpa sigue torturando a los ciudadanos cada vez que siguen sus instintos! Por esto es por lo que si hay algo cierto en el acreedor originario y democrático es que el llamado pueblo soberano debe ser honrado por cada ciudadano por su misericordia, pero sigue siendo el mismo Dios que es incapaz de asumir la culpa. En otras palabras, cuando creíamos haber matado al Dios cristiano, nos dimos cuenta de que se puso la mascara de la Democracia...

Así, se supone que la adoración pública a nuestros antepasados se remonta al presupuesto del orden social democrático, pero nadie se tomaría en serio a alguien que dijera que el error, el estado de necesidad, el dolo, la imprudencia o el delito de aborto fueron establecidos recientemente como producto de la deliberación laica y, por este motivo, no se va a decir. Hemos explicado cómo en varios versículos de la Biblia se

163. Todo el párrafo es una interpolación de la Carta a los romanos del apóstol San Pablo. 
encuentran formulaciones anticuadas del error de prohibición y de la responsabilidad personal, así como de la distinción entre actos intencionales y no intencionales. También mostramos el estrecho vínculo entre las teorías platónico-aristotélicas y la pecaminosidad cristiana para luego, de la mano de Nietzsche, concluir que la mala conciencia y la idea de un individuo soberano son el producto de dolorosos ejercicios mnemotécnicos cuyas explicaciones han sido adaptadas interpretativamente a lo largo del tiempo. Nuestra conclusión sobre el castigo es que las explicaciones y las normas son distintas, pero se sigue utilizando alguna forma de libertad y de culpa para garantizar el orden social, esto es, para que los «colegisladores» no olviden cómo deben actuar para que no les pase lo que no-quieren.

Algunas ideas suelen rondar por las cabezas de los providencialistas seculares y, para descolgar las estrellas que han puesto en el firmamento, es hora de preguntarnos ¿quién tiene la suerte de participar? ¿Cómo utiliza su fortuna? ¿Con qué actitud se le escucha? ¿Para qué habla? La deliberación no debe ser una mera aspiración que eventualmente estandariza indistintamente la legitimación de la voluntad de poder. Una concepción de libertad negativa, bajo la excusa de que quienes no participaron en el procedimiento discursivo tuvieron la «oportunidad» de deliberar, esconde la creciente desigualdad de las sociedades occidentales. La vida ética de una democracia conlleva la realización de la idea de la deliberación, no simplemente la formulación de condiciones comunicativas abstractas. La deliberación compromete discursos racionales y legitimidad procedimental hasta cierto punto, pero también una estructura social que garantice y valore la participación de todos en la definición del bien común. Por ende, esta no es posible en un sistema al que no se pertenece verdaderamente.

\section{Referencias}

Agretelis, Demetrios (1965). ««Mens Rea» in Plato and Aristotle». Issues in Criminology, 1 (19): 19-33. Disponible en bit.ly/34X26t4.

Aristóteles (2005). Ética a Nicómaco. Madrid: Alianza.

Carlson, David Gray (2013). «Effect Precedes Cause: Kant and the Self-in-Itself». Washington University Jurisprudence Review, 6 (1): 161-173.

DíAz, Jorge Aurelio (2004). «La crítica de Hegel a Kant». En Luis Eduardo Hoyos (compilador), Estudios de filosofía política (pp. 251-266). Bogotá D.C.: Universidad Externado de Colombia.

Feijóo SÁnCHEZ, Bernardo José (2002). Imputación objetiva en derecho penal. Monografías Penales. 1. ${ }^{a}$ ed. Lima: Grijley.

Foucault, Michel (1967). La historia de la locura en la época clásica. Tomo II. Trad. por Juan José Utilla. México D.F.: Fondo de Cultura Económica.

-. (2010). La arqueología del saber. México D.F.: Siglo XXI. 
-. (2018). Las palabras y las cosas. Trad. Cecilia Elsa Frost. México D.F.: Siglo XXI.

Franco, Paul (1997). «Hegel and Liberalism». The Review of Politics, 59 (4): 831-860. Disponible en bit.ly/2TRilLW.

GÜNTHER, Klaus (1991). «Möglichkeiten einer diskursethischen Begründung des Strafrechts». En Recht und Moral: Beiträge zu einer Standortbestimmung (pp. 205217). Baden-Baden: Nomos.

-. (1994). «Individuelle Zurechnung im Demokratischen Verfassungsstaat». Jahrbuch für Recht und Ethik, 2 (143): 143-158. Disponible en bit.ly/2GwXi4s.

-. (1999). «Welchen Personenbegriff braucht die Diskurstheorie des Rechts? Überlegungen zum internen Zusammenhang zwischen deliberativer Person, Staatsbürger und Rechtsperson». En Hauke Brunkhorst y Peter Niesen (compiladores), Das Recht der Republik (pp. 83-104). Fráncfort del Meno: Suhrkamp.

-. (2003). «Voluntary Action and Criminal Responsibility». En Sabine Maasen Wolfgang Prinz y Gerhard Roth (compiladores), Brains, Minds, and Society (pp. 263280). Oxford: Oxford University Press.

-. (2014). Criminal Law, Crime and Punishment as Communication. Normative Orders Working Paper. Tomo 2. Fráncfort del Meno: Goethe-Universität.

-. (1999). «Welchen Personenbegriff braucht die Diskurstheorie des Rechts? Überlegungen zum internen Zusammenhang zwischen deliberativer Person, Staatsbürger und Rechtsperson». En Hauke Brunkhorst y Peter Niesen (compiladores), Das Recht der Republik (pp. 83-104). Fráncfort del Meno: Suhrkamp.

Habermas, Jürgen (1991). "¿Afectan las objeciones de Hegel a Kant también a la ética del discurso?». En Escritos sobre moralidad y eticidad (pp. 97-130). Trad. por Manuel Jiménez Redondo. Barcelona: Paidós.

-. (1992). Teoría de la acción comunicativa. Tomo I. Madrid: Taurus.

-. (1996). «Ética del discurso: Notas sobre un programa de fundamentación». En Conciencia moral y acción comunicativa (pp. 57-134). Trad. por Ramón García Cotarelo. Barcelona: Península.

-. (1998). Facticidad y validez. Trad. por Manuel Jiménez Redondo. Madrid: Trotta.

-. (2003). «On Law and Disagreement: Some Comments on Interpretative Pluralism». Ratio Juris, 16 (2): 187-194. Disponible en bit.ly/2TRpAdı.

Hegel, Georg Wilhelm Friedrich (1968). Filosofía del derecho. Trad. por Angélica Mendoza de Montero. Buenos Aires: Claridad.

-. (1979). Sobre las maneras de tratar científicamente el derecho natural. Trad. por Dalmacio Negro Pavon. Madrid: Aguilar.

-. (2005). Enciclopedia de las ciencias filosóficas. Trad. por Ramón Valls Plana. Madrid: Alianza editorial.

Honig, Richard (2009). Causalidad e imputación objetiva. Causalidad, Riesgo e Imputación. Compilado por Marcelo A. Sancinetti. Buenos Aires: Hammurabi. 
Hörnle, Tatjana (2015). Teorías de la pena. Colección de Estudios. Bogotá D.C.: Universidad Externado de Colombia.

Houlgate, Stephen (1995). «The Unity of Theoretical and Practical Spirit in Hegel's Concept of Freedom». The Review of Metaphysics, 48 (4): 859-881. Disponible en bit.ly/2I980mP.

Hoyos, Luis Eduardo (2003). «La filosofía práctica de Immanuel Kant». En Luis Eduardo Hoyos (compilador), Lecciones de Filosofía (pp. 223-250). Bogotá D.C.: Universidad Externado de Colombia.

-. (2004). «La actualidad de Kant». En Luis Eduardo Hoyos (compilador), Estudios de filosofía política (pp. 197-220). Bogotá D.C.: Universidad Externado de Colombia.

HruschKa, Joachim (1994). «Reglas de comportamiento y reglas de imputación». Anuario de Derecho Penal y Ciencias Penales, 47 (3): 343-356. Disponible en bit. ly/zerEGPH.

JАковS, Günther (1994). La imputación objetiva en el derecho penal. 1. ${ }^{\mathrm{a}}$ ed. Trad. por Manuel Cancio Meliá. Bogotá D.C.: Universidad Externado de Colombia.

-. (1995). Derecho penal. Parte general: Fundamentos y teoría de la imputación. Madrid: Marcial Pons.

-. (2003). Culpabilidad en derecho penal: Dos cuestiones fundamentales. Bogotá: Universidad Externado de Colombia.

-. (2004). «La pena estatal: Significado y finalidad». Doctrina y Jurisprudencia Penales, (5): 171-221.

JAmES, David (2012). «Subjective Freedom and Necessity in Hegel's «Philosophy of Right»». A Journal of Social and Political Theory, 59 (131): 41-63. Disponible en bit. ly/3piiwce.

Kant, Immanuel (1951). Crítica de la razón práctica. Buenos Aires: El Ateneo.

-. (2003). Crítica de la razón pura. Trad. por Pedro Ribas. Madrid: Alfaguara.

-. (2006). Fundamentación para una metafísica de las costumbres. Trad. por Roberto Rodríguez Aramayo. Madrid: Alianza.

-. (2008). La metafísica de las costumbres. Madrid: Tecnos.

KINDHÄUSER, Urs (2009). «La lógica de la construcción del delito». Revista de Análisis Especializado de Jurisprudencia, (14): 499-509.

Lesch, Heiko (1999). La función de la pena. 1. a ed. Bogotá D.C.: Universidad Externado de Colombia.

Levitt, Albert (1922-1923). «Origin of the Doctrine of Mens Rea». Illinois Law Review, 17 (2): 117-137. Disponible en bit.ly/3pSnfob.

López HernándeZ, José (200o). «Actualidad y vigencia de la filosofía del derecho de Hegel». Revista de Estudios Políticos (Nueva Época), (110): 175-195. Disponible en bit.ly/34YVavE. 
Mañalich R., Juan Pablo (2010). «Norma e imputación como categorías del hecho punible». Revista de Estudios de la Justicia, (12): 169-170. Disponible en bit. ly/3kZWYuz.

McWherter, Dustin (2016). «The Moore-Walker Dilema: A Critique of Transcendental Idealism». The Philosophical Forum, 42 (2): 195-206. Disponible en bit. ly/3eyhorx.

Nietzsche, Friedrich Wilhelm (1996). El Anticristo: Maldición sobre el cristianismo. Trad. por Andrés Sánchez Pascual. Madrid: Alianza.

-. (2011a). Así habló Zaratustra: Un libro para todos y para nadie. Trad. por Andrés Sánchez Pascual. Madrid: Alianza.

-. (2011b). La genealogía de la moral: Un escrito polémico. Trad. por Andrés Sánchez Pascual. Madrid: Alianza.

-. (2016). La gaya ciencia. Trad. Juan Luis Vermal. Madrid: Tecnos.

Oppenheimer, Heinrich (1913). Rationale of Punishment. Monographs on Sociology. Londres: University of London Press.

Paulsen, Friedrich (1902). Immanuel Kant: His Life and Doctrine. Trad. por J. E. Creighton y Albert Lefevre. Nueva York: Charles Scribner's Sons.

Pawlik, Michael (2005). «Hegel y la racionalidad de lo real». Trad. por Jorge Fernando Perdomo Torres. En La realidad de la libertad. Bogotá: Universidad Externado de Colombia.

Platón (1992). La república. Madrid: Aguilar.

-. (2016). Gorgias. Santiago: Universitaria.

Reyes Alvarado, Yesid (1992). «Fundamentos teóricos de la imputación objetiva». Anuario de Derecho Penal y Ciencias Penales, 45 (3): 933-968. Disponible en bit. ly/38igZIR.

RoHLF, Michael (2018). «Immanuel Kant». En Edward N. Zalta (compilador), The Stanford Encyclopedia of Philosophy. Stanford: The Metaphysics Research Lab, Center for the Study of Language and Information. Stanford: Stanford University. Disponible en stanford.io/3pTeUZX.

Roxin, Claus (1997). Derecho penal. Parte general: Fundamentos. La estructura de la teoría del delito. Tomo I. Madrid: Civitas.

-. (2013). La imputación objetiva en su significado para la teoría del tipo penal. Política Criminal y Dogmática Penal: Cuestiones Fundamentales. Lima: ARA.

San Agustín de Hipona (1981). La CiUdad de Dios. México D.F.: Porrúa.

SAUnders, Joe (2016). «Kant and the Problem of Recognition: Freedom, Transcendental Idealism, and the Third-Person». International Journal of Philosophical Studies, 24 (2): 164-182. Disponible en bit.ly/2TQYti8.

Schopenhauer, Arthur (2001). Metafísica de las costumbres. Trad. por Roberto Rodríguez Aramayo. Madrid: Trotta. 
Searle, John R. (1991). «How Performatives Work». Tennessee Law Review, 58 (3): 371-392. Disponible en bit.ly/3k2xdI6.

SEdgwick, Sally S. (1996). «Hegel's Critique of Kant's Empiricism and the Categorical Imperative». Zeitschrift für philosophische Forschung, 50 (4): 563-584. Disponible en bit.ly/388GXij.

-. (2010). «Reason and History: Kant versus Hegel». Proceedings and Addresses of the American Philosophical Association, 84 (2): 45-59. Disponible en bit.ly/38dmbh6.

Sмiтн, Steven B. (1986). "Hegel's Critique of Liberalism». The American Political Science Review, 8o (1): 121-139. Disponible en bit.ly/3oZY4bF.

Tito Livio (1990). Historia de Roma desde su fundación: Libros VIII-X [versión para Kindle]. Trad. por José Antonio Villar Vidal. Madrid: Gredos.

Von Hirsch, Andrew (1998). Censurar y castigar. Valladolid: Trotta.

WestphaL, Kenneth R. (1991). «Hegel's Critique of Kant's Moral World View». Philosophical Topics, 19 (2): 133-176. Disponible en bit.ly/3mR2y2j.

Wood, Allen W. (1991). «Does Hegel Have an Ethics?». The Monist, 74 (3): 358-385. Disponible en bit.ly/2TWdoYw.

ZACZYK, Rainer (2010a). «La culpabilidad como concepto jurídico». Trad. por Nathalia Bautista. En Libertad, derecho y fundamentación de la pena (pp. 176-194). Bogotá D.C.: Universidad Externado de Colombia.

-. (2010b). ««Ha matado, entonces debe morir». Kant y el derecho penal». En Libertad, derecho y fundamentación de la pena (pp. 109-133). Bogotá D.C.: Universidad Externado de Colombia.

\section{Agradecimientos}

Le agradezco a la doctora Nathalia Bautista Pizarro y al profesor Fernando Arboleda Ripoll de la Universidad Externado de Colombia por su sincera crítica y generosos aportes.

\section{Sobre el autor}

Nicolás Otero Álvarez es abogado de la Universidad Externado de Colombia. Ahí, formó parte del Centro de Investigación en Filosofía y Derecho hasta 2018 bajo la dirección del doctor Yesid Reyes Alvarado. Actualmente, investiga sobre filosofía del derecho de forma independiente. Su correo electrónico es nicolas.otero@aol.com. (iD) https://orcid.org/0000-0001-6973-6049. 
La Revista de Estudios de la Justicia es publicada, desde 2002, dos veces al año por el Centro de Estudios de la Justicia de la Facultad de Derecho de la Universidad de Chile. Su propósito es contribuir a enriquecer el debate jurídico en el plano teórico y empírico, poniendo a disposición de la comunidad científica el trabajo desarrollado tanto por los académicos de nuestra Facultad como de otras casas de estudio nacionales y extranjeras.

\author{
DIRECTOR \\ Álvaro Castro \\ (acastro@derecho.uchile.cl) \\ SITIO WEB \\ rej.uchile.cl \\ CORREO ELECTRÓNICO \\ cej@derecho.uchile.cl \\ LICENCIA DE ESTE ARTÍCULO \\ Creative Commons Atribución Compartir Igual 4.o Internacional
}

La edición de textos, el diseño editorial y la conversión a formatos electrónicos de este artículo estuvieron a cargo de Tipográfica

(www.tipografica.io) 